Article

\title{
Advanced Heterogeneous Fenton Treatment of Coalbed Methane-Produced Water Containing Fracturing Fluid
}

\author{
Meng Zhang ${ }^{1,2}$ and Wei Gu ${ }^{1, *}$ \\ 1 State Key Laboratory of Coal Resources and Mine Safety, China University of Mining \& Technology, \\ Xuzhou 221116, China; zhangmeng@cumt.edu.cn \\ 2 School of Mines, Key Laboratory of Deep Coal Resource Mining, Ministry of Education of China, \\ China University of Mining \& Technology, Xuzhou 221116, China \\ * Correspondence: weigu@cumt.edu.cn
}

Received: 24 March 2018; Accepted: 19 April 2018; Published: 24 April 2018

\begin{abstract}
This study investigated the heterogeneous Fenton treatment to process coalbed methane-produced water containing fracturing fluid and chose the development region of coalbed methane in the Southern Qinshui Basin as a research area. We synthesized the catalyst of $\mathrm{Fe}-\mathrm{Co} / \gamma-\mathrm{Al}_{2} \mathrm{O}_{3}$ by homogeneous precipitation method and characterized it by BET, XRD, SEM-EDS, FTIR, and XPS. Based on the degradation rate, we studied the influences of the heterogeneous Fenton method on the coalbed methane output water treatment process parameters, including initial $\mathrm{pH}, \mathrm{H}_{2} \mathrm{O}_{2}$ concentration, and the catalyst concentration. We also investigated the impacts of overall reaction kinetics of heterogeneous catalytic oxidation on coalbed methane-produced water containing fracturing fluid. Results showed that $\mathrm{Fe}-\mathrm{Co} / \gamma-\mathrm{Al}_{2} \mathrm{O}_{3}$ as a Fenton catalyst has a good catalytic oxidation effect and can effectively process coalbed methane-produced water. This reaction also followed first-order kinetics. The optimal conditions were as follows: the initial $\mathrm{pH}$ of $3.5, \mathrm{a}_{2} \mathrm{O}_{2}$ concentration of $40 \mathrm{~mol} \mathrm{~L}^{-1}$, a catalyst concentration of $4 \mathrm{~g} / \mathrm{L}$, and an apparent reaction rate constant of $0.0172 \mathrm{~min}^{-1}$. Our results provided a basis to establish methods for treating coalbed methane-produced water.
\end{abstract}

Keywords: catalyst; methane; Fenton treatment; produced water; environmental protection

\section{Introduction}

Coalbed methane is an important source of natural gas that is produced during coal formation and found in coal seams in an adsorbed state [1,2]. Coalbed methane is generally produced through drainage and pressure lowering [3]. In this process, coalbed methane-produced water is also produced. After undergoing water-rock and water-gas interactions, the quality and quantity of this type of water change greatly, yielding a complicated composition. It causes soil salinization and surface and ground water pollution if is discharged directly into the environment. And these pollutions cause an adverse impact on industrial and agricultural production as well as human health. Most coalbed methane reserves in China are concentrated in arid north and northwest regions. If coalbed methane-produced water in these regions can be appropriately treated and utilized for industrial purposes, irrigation, or drinking water sources, water shortage could be significantly alleviated.

As stated above, the compositions of the water produced from coalbed methane could be very complicated. Generally speaking, the major compositions are limited to the solved ions, including both cations and anions, and organics from the chemicals used in the methane extraction process, while the compositions of trace metals and isotopic chemicals are rarely reported. Specifically, the ions in the water produced from coalbed methane include Sodium $(\mathrm{Na})$, bicarbonate $\left(\mathrm{HCO}_{3}^{-}\right)$, 
Calcium (Ca), sulfate ( $\left.\mathrm{SO}_{4}^{2-}\right)$, Magnesium (Mg) and other Total Dissolved Solids (TDS), depending on the geographical locations of the wells [4].

The management and treatment of coalbed methane-produced water have been of great interest to engineers and scientists. So far, two typical options have been proposed so far. The first treatment method is disposal by reinjection. In the method, the produced water is injected to the deep underground, so that it will not bring direct side impacts to the environment and human beings on the ground. This option is only applicable for small amounts and for non-harmful water. By now, this option has been used in the San Juan Basin (New Mexico State) and the Piceance Basin (Colorado State) in the United States of America (USA) [5]. The biggest advantage of this method is the low cost. The second treatment method is direct disposal to waterways. To achieve this, the produced water should be treated with various chemical and/or physical methods to meet the national and local regulations on water quality. Most of the Basins in the world tend to have effective methods to treat the produced water from coalbed methane [6].

The major physical methods include reverse osmosis (RO), ion exchange (IE), microfiltration (MF), and ultrafiltration (UF) technologies. These technologies can effectively remove the ions in the produced water, so that the treated water can reach the standards for irritation and industrial applications. However, in most cases, when the organics are included in the produced water, physical methods may not be very effective. In this case, chemical methods can be used. Specifically, chemical absorption [7] and oxidation [8-10] were employed to treat the water produced from coalbed methane extraction. However, overuse of treatment agents, large investment in infrastructure, and complicated technological processes increase the cost of fracturing wastewater treatment [11-14]. Among the various oxidation techniques, heterogeneous Fenton method [15] is one of the most popular one because of tis high efficiency, low cost, and easy operation. It has been widely used for the treatment of waste water from the printing and dyeing [4,16], pharmaceutical $[5,17]$, and coal-chemical engineering $[18,19]$ industries.

However, challenges still exist for the further application of the Fenton method for coalbed methane produced water.

Firstly, the generation and utilization rates of hydroxyl radical are not high [20,21]. The key to improve the efficiency of Fenton treatment in the process of wastewater treatment is to improve the production and utilization rates of hydroxyl radical in the system. However, based on a large number of experimental studies, the total amount of $\mathrm{H}_{2} \mathrm{O}_{2}$ required for complete mineralization of unit wastewater is much higher than the theoretical calculations, which shows that the generation and utilization rates of hydroxyl radicals are not high. More importantly than all of that, the low generation and utilization rates of hydroxyl radical have a negative impact on the Fenton reaction rate and pollutant removal efficiency.

Secondly, the strict reaction conditions easily lead to secondary pollution $[22,23]$. The Fenton reaction treatment of wastewater with high efficiency is achieved in reaction conditions that require accurate control of the reaction system $\mathrm{pH}$ value, and the dosage and proportion of $\mathrm{H}_{2} \mathrm{O}_{2}$ and $\mathrm{Fe}^{2+}$, which limits the application of Fenton advanced oxidation technology to a considerable extent and increases the cost of wastewater treatment. Although hydroxylation of iron ions has a good coagulation effect, it is beneficial for the removal of pollutants. However, at the same time, it also contains $\mathrm{Fe}^{3+}$ ions, which cause secondary pollution.

Finally, the cost of processing was too high [24]. The reasons for the higher processing costs lie in two aspects: one is that the Fenton reagent costs more, and the other is that the limit of Fenton reaction conditions ( $\mathrm{pH}$, temperature, inorganic ions, etc.) increases the wastewater treatment cost.

Based on the reasons above, our research team has been working on the improvement of a Fenton reaction system to enhance the capacity and reduce the cost of coalbed methane water treatment. $\mathrm{Fe} / \gamma-\mathrm{Al}_{2} \mathrm{O}_{3}$ and $\mathrm{Fe}-\mathrm{Co} / \gamma-\mathrm{Al}_{2} \mathrm{O}_{3}$ catalysts were synthesized and applied for coalbed methane water treatment in this paper. Compared to $\mathrm{Fe} / \gamma-\mathrm{Al}_{2} \mathrm{O}_{3}$, Cobalt is added to $\mathrm{Fe}-\mathrm{Co} / \gamma-\mathrm{Al}_{2} \mathrm{O}_{3}$, which could potentially increase the Fenton reaction's ability to convert a broad range of pollutants to less harmful 
products $[25,26]$. It is noted that $\mathrm{Co} / \gamma-\mathrm{Al}_{2} \mathrm{O}_{3}$ catalyst was not synthesized for the experiment, as $\mathrm{Fe}$ is an indispensable part in Fenton reaction system [27].

\section{Experimental Materials and Methods}

\subsection{Main Reagents and Instruments}

Deionized water was used in the experiment. The following chemicals were used: $\gamma-\mathrm{Al}_{2} \mathrm{O}_{3}$ (Zibo Superco Alumina Material Co. LTD, Zibo, China, 99.8\%), ferrous sulfate $\left(\mathrm{FeSO}_{4} \bullet 7 \mathrm{H}_{2} \mathrm{O}\right.$, Sigma Aldrich, St. Louis, MO, USA, $>97 \%)$, cobalt sulfate $\left(\mathrm{CoSO}_{4} \bullet 7 \mathrm{H}_{2} \mathrm{O}\right.$, Sigma Aldrich, $99.8 \%$ trace metals basis), urea $\left(\mathrm{CO}\left(\mathrm{NH}_{2}\right)_{2}\right.$, Sigma Aldrich, $\left.>98 \%\right)$ sulfuric acid $\left(\mathrm{H}_{2} \mathrm{SO}_{4}\right.$, Sigma Aldrich, $\left.>96 \%\right)$, hydrochloric acid ( $\mathrm{HCl}$, Sigma Aldrich, 37\%), and 30\% hydrogen peroxide $\left(\mathrm{H}_{2} \mathrm{O}_{2}\right.$, Sigma Aldrich, $30 \%(\mathrm{w} / \mathrm{w})$ in $\left.\mathrm{H}_{2} \mathrm{O}\right)$. The following instruments were also used: electronic analytical balance, $\mathrm{COD}$ fast detector, thermostat shaker, water bath cauldron, constant-temperature drying oven, $\mathrm{X}$-ray diffractometer (XRD), scanning electron microscope (SEM), surface area analyzer, X-ray fluorescence spectrometer, Fourier transform infrared spectrometer, $\mathrm{X}$-ray photoelectron spectrometer, $\mathrm{pH}$ meter, and ICP-AES analyzer.

\subsection{Catalyst Preparation}

\subsubsection{Homogeneous Precipitation Method}

Supported catalysts are typically prepared using an ordinary impregnation method. In this method, active species enriched in or deposited in a carrier weakly and strongly interact with carriers simultaneously; as a result, active components are non-uniformly distributed. To solve this problem, researchers developed a homogeneous precipitation method by facilitating the interaction between a metal salt solution and an alkali. Thus, metal hydroxides or carbonates are precipitated in carrier particles. At low temperatures, urea $\left[\mathrm{CO}\left(\mathrm{NH}_{2}\right)_{2}\right]$, as a weak base, does not hydrolyze. Above $90{ }^{\circ} \mathrm{C}$, urea undergoes hydrolysis [Equation (1)]; in this reaction, $\mathrm{OH}^{-}$is slowly released, thereby causing the active components to be uniformly distributed in the carrier particles.

$$
\mathrm{CO}\left(\mathrm{NH}_{2}\right)_{2}+3 \mathrm{H}_{2} \mathrm{O} \rightarrow 2 \mathrm{NH}_{4}^{+}+2 \mathrm{OH}^{-}+\mathrm{CO}_{2}
$$

\subsubsection{Preparation of Carriers Supported on $\mathrm{Fe}-\gamma-\mathrm{Al}_{2} \mathrm{O}_{3}$}

$\gamma-\mathrm{Al}_{2} \mathrm{O}_{3}(2 \mathrm{~g})$ was placed in a $300 \mathrm{~mL}$ glass conical flask, and deionized water $(200 \mathrm{~mL})$ was added. $\mathrm{FeSO}_{4} \bullet 7 \mathrm{H}_{2} \mathrm{O}(0.596 \mathrm{~g}, 2.14 \mathrm{mmol})$ was added into the conical flask at the iron to carrier ratio of $6 \%(\mathrm{w} / \mathrm{w})$ and mixed through ultrasonic vibration for $10 \mathrm{~min}$. Urea $(0.385 \mathrm{~g}, 6.42 \mathrm{mmol})$ was dissolved in the resulting suspension to ensure the molar ratio of urea to $\mathrm{Fe}^{2+}$ is 3:1. Afterward, the mixture was placed in a shaker with a constant temperature of $20^{\circ} \mathrm{C}$ and shaken at $150 \mathrm{r} / \mathrm{min}$ for $30 \mathrm{~min}$ to completely dissolve the urea and evenly mix the suspension. The suspension was heated in a water bath at $95^{\circ} \mathrm{C}$ and mechanically stirred at $200 \mathrm{r} / \mathrm{min}$ for $2 \mathrm{~h}$ to complete the precipitation. The suspension was stirred and then left untouched to promote aging for $3 \mathrm{~h}$; afterward, the suspension was filtered through a $0.45 \mu \mathrm{m}$ membrane. The precipitate was obtained and alternately washed with deionized water and ethanol several times until no sulfate ions were detected using $\mathrm{BaCl}_{2}$ solution. The product was finally formed, dried at $105^{\circ} \mathrm{C}$ for $1 \mathrm{~h}$, and baked in a muffle furnace at $300{ }^{\circ} \mathrm{C}$ for $4 \mathrm{~h}$.

\subsubsection{Preparation of the Co-Doped $\mathrm{Fe}-\gamma-\mathrm{Al}_{2} \mathrm{O}_{3}$ Carrier}

It is known that the $\mathrm{pH}$ values of the hydroxide precipitate of $\mathrm{Co}$ and $\mathrm{Fe}$ are similar; therefore, these elements can co-precipitate on a carrier surface. Co-doped $\mathrm{Fe}-\gamma-\mathrm{Al}_{2} \mathrm{O}_{3}$ carrier was prepared, as in Step (1). Iron and cobalt mixture was used as a precursor for the metal salt solution. $\mathrm{FeSO}_{4} \bullet 7 \mathrm{H}_{2} \mathrm{O}$ $(0.298 \mathrm{~g}, 1.07 \mathrm{mmol})$ was added at the iron to carrier ratio of $3 \%(\mathrm{w} / \mathrm{w})$, and $\mathrm{CoSO}_{4} \bullet 7 \mathrm{H}_{2} \mathrm{O}(0.286 \mathrm{~g}$, 
$1.07 \mathrm{mmol})$ was added to obtain a $\mathrm{Fe}^{2+}$ to $\mathrm{Co}^{2+}$ molar ratio of $1: 1$. Urea $(0.385 \mathrm{~g}, 6.42 \mathrm{mmol})$ was dissolved in the resulting suspension to ensure the molar ratio of urea to $\left(\mathrm{Fe}^{2+}+\mathrm{Co}^{2+}\right)$ is 3:1.

\subsection{Catalyst Characterization Instruments}

An X-ray diffractometer was used to analyze the crystal structure; a scanning electron microscope was used to observe particle morphological characteristics, particle size, and agglomeration; a specific surface area analyzer was used to determine the specific composite surface.

SEM test: An FEI Quanta ${ }^{\mathrm{TM}} 250$ scanning electron microscope (USA) was used in high vacuum mode with magnification of $6 \times$ to $1,000,000 \times$ and acceleration voltage of $0.2 \mathrm{kV}$ to $30 \mathrm{kV}$.

EDS test: A Bruker QUANTAX400-10 X-ray detector with electric cooling (Germany) was used. This test was performed under the following conditions: effective detection area of detection chip, $10 \mathrm{~mm}^{2}$; energy resolution, MnKa resolution superior to $129 \mathrm{eV}$ (1000 cps to 100,000 cps testing condition); maximum input count, 1,000,000 cps; maximum output count, 400,000 cps; window type, ultrathin light element detection window; element detection range, Be (4)-Am (95), which can support a pixel resolution of $4096 \times 3072$; and mapping system stability, input count (peak-to-peak) offset within 1,000,000 cps not exceeding $1 \mathrm{eV}$.

XRD test: A Bruker D8 Advance XRD (Germany) was used. The specific parameters are as follows: X-ray tube with a voltage of $40 \mathrm{kV}$ and current of $30 \mathrm{~mA}$; $\mathrm{Cu}$ target as anode target material with Ka radiation and a goniometer radius of $250 \mathrm{~mm}$; Slit systems, including a divergence slit (DS) of $0.6 \mathrm{~mm}$ and anti-scatter slit (SS) of $8 \mathrm{~mm}$; Ni filter to filter $\mathrm{Cu}-\mathrm{K} \beta$ ray with a detector opening of $2.82^{\circ}$; Soller slit of $2.5^{\circ}$ between an incident side and a diffraction side with a sampling interval of 0.019450 (step) and

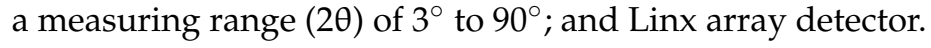

XPS test: A Thermo Fisher ESCALAB 250Xi X-ray photoelectron spectrometer (USA) was used.

BET test: A Micromeritics ASAP 2460 surface area and porosimetry analyzer (USA) was used with $\mathrm{N}_{2}$ as an adsorbate at $77.4 \mathrm{~K}$. Before the measurements were performed, the samples were subjected to vacuum pumping at $373 \mathrm{~K}$ for more than $10 \mathrm{~h}$. The specific surface area and pore size distributions of the samples were obtained using BET and BJH methods.

XRF test: A Bruker S8 TIGER X-ray fluorescence spectrometer (Germany) was used. Samples were crushed to 200 -mesh $(74 \mu \mathrm{m})$ or less and dried at $105^{\circ} \mathrm{C}$ for $2 \mathrm{~h}$. Scanning was performed at a sequential mode with power of $4 \mathrm{~kW}$, maximum voltage of $60 \mathrm{kV}$, and maximum current of $170 \mathrm{~mA}$.

FT-IR test: A Bruker Vertex 80v FTIR instrument and a micro-infrared system (Germany) were used. A sample was dried, crushed to 200-mesh or less, and transformed into a $\mathrm{KBr}$ tablet. Scanning was performed at a spectral range of $4000 \mathrm{~cm}^{-1}$ to $400 \mathrm{~cm}^{-1}$, a resolution of $0.06 \mathrm{~cm}^{-1}$, and a beam diameter of $40 \mathrm{~mm}$.

\subsection{Test Methods}

(1) Heterogeneous catalysis testing: The effluent $(200 \mathrm{~mL})$ after coagulation pretreatment was collected and placed in a $350 \mathrm{~mL}$ conical flask. A specific amount of catalyst and $\mathrm{H}_{2} \mathrm{O}_{2}$ was added to adjust the initial $\mathrm{pH}$. At $25{ }^{\circ} \mathrm{C}$, the sample was oscillated in a thermostat shaker at $150 \mathrm{rpm}$. After a predetermined reaction time was reached, $10 \mathrm{~mL}$ of solution was filtered with a $0.45 \mu \mathrm{m}$ membrane. The $\mathrm{pH}$ of the filtered water was adjusted to $>10$. After the effect of $\mathrm{H}_{2} \mathrm{O}_{2}$ residue was removed, $\mathrm{COD}_{\mathrm{Cr}}$ was determined. Using this method, we determined the effects of different catalyst dosage, $\mathrm{H}_{2} \mathrm{O}_{2}$ dosage, and initial $\mathrm{pH}$ values, as well as iron dissolution on the treatment of the effluent from coagulation pretreatment.

(2) Heterogeneous/homogeneous catalysis comparison testing: Heterogeneous/homogeneous catalysis comparison testing was conducted in two conical flasks $(350 \mathrm{~mL}$ ) with $200 \mathrm{~mL}$ effluent. The temperature was $25^{\circ} \mathrm{C}, \mathrm{H}_{2} \mathrm{O}_{2}$ concentration was $40 \mathrm{mmol} / \mathrm{L}$, the initial $\mathrm{pH}$ was 5.1. In one flask, $0.8 \mathrm{~g}$ of $\mathrm{Fe}-\gamma-\mathrm{Al}_{2} \mathrm{O}_{3}$ added in to the solution for heterogeneous Fenton reaction. In the other flask, $\mathrm{FeSO}_{4} \bullet 7 \mathrm{H}_{2} \mathrm{O}(0.856 \mathrm{mmol})$ was added to the solution for homogenous Fenton reaction. The molar ratio of $\mathrm{Fe}^{2+}$ in two flasks were controlled to be 1:1. The samples were oscillated in 
a thermostat shaker at $150 \mathrm{rpm}$. After a predetermined reaction time was reached, $10 \mathrm{~mL}$ of solution was filtered with a $0.45 \mu \mathrm{m}$ membrane. The $\mathrm{pH}$ of the filtered water was adjusted to $>10$. After the effect of $\mathrm{H}_{2} \mathrm{O}_{2}$ residue was removed, $\mathrm{COD}_{\mathrm{Cr}}$ was determined.

\section{Catalyst Characterization SEM and EDS Characterization}

\subsection{SEM and EDS Characterization}

$\gamma-\mathrm{Al}_{2} \mathrm{O}_{3}, \mathrm{Fe} / \gamma-\mathrm{Al}_{2} \mathrm{O}_{3}$, and $\mathrm{Fe}-\mathrm{Co} / \gamma-\mathrm{Al}_{2} \mathrm{O}_{3}$ samples were characterized using SEM and EDS to directly observe the surface morphological characteristics of carriers and catalysts and qualitatively analyze the elemental composition, and the corresponding results are shown in Table 1 and Figure 1.

Table 1. The EDS data summary for $\gamma-\mathrm{Al}_{2} \mathrm{O}_{3}, \mathrm{Fe} / \gamma-\mathrm{Al}_{2} \mathrm{O}_{3}$ and $\mathrm{Fe}-\mathrm{Co} / \gamma-\mathrm{Al}_{2} \mathrm{O}_{3}$.

\begin{tabular}{cccc}
\hline \multirow{2}{*}{ Elements } & $\gamma-\mathrm{Al}_{2} \mathrm{O}_{3}$ & $\mathrm{Fe} / \gamma-\mathrm{Al}_{\mathbf{2}} \mathrm{O}_{3}$ & $\mathrm{Fe}-\mathrm{Co} / \gamma-\mathrm{Al}_{\mathbf{2}} \mathrm{O}_{3}$ \\
\cline { 2 - 4 } & Atomic Percentage & Atomic Percentage & Atomic Percentage \\
\hline $\mathrm{C}$ & $70.25 \%$ & $61.27 \%$ & $69.70 \%$ \\
$\mathrm{O}$ & $26.30 \%$ & $28.44 \%$ & $24.32 \%$ \\
$\mathrm{Al}$ & $3.45 \%$ & $9.92 \%$ & $5.97 \%$ \\
$\mathrm{Fe}$ & $0.00 \%$ & $0.38 \%$ & $0.14 \%$ \\
$\mathrm{Co}$ & $0.00 \%$ & $0.00 \%$ & $0.05 \%$ \\
\hline
\end{tabular}
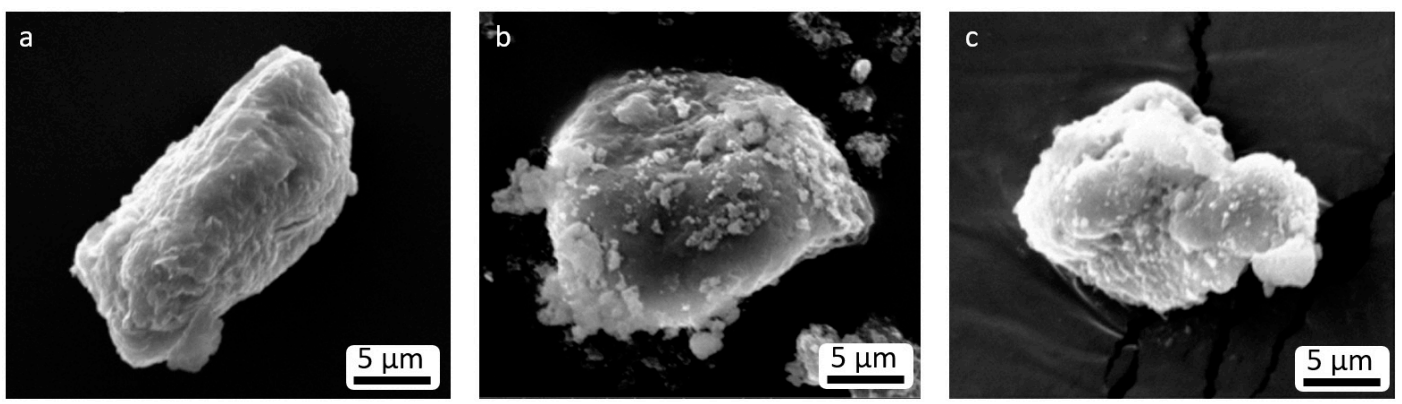

Figure 1. Scanning electron microscopy (SEM) images of (a) $\gamma-\mathrm{Al}_{2} \mathrm{O}_{3} ;(\mathbf{b}) \mathrm{Fe} / \gamma-\mathrm{Al}_{2} \mathrm{O}_{3} ;$ (c) $\mathrm{Fe}-\mathrm{Co} / \gamma-\mathrm{Al}_{2} \mathrm{O}_{3}$.

$\gamma-\mathrm{Al}_{2} \mathrm{O}_{3}$ : A typical optical photograph showed that the sample is white. In Figure $1 \mathrm{a}$, the carrier surface was smooth with a metallic luster. The spectra also indicated that the sample contains aluminum, oxygen, potassium, and carbon. Aluminum and oxygen were the main components of the $\gamma-\mathrm{Al}_{2} \mathrm{O}_{3}$ carrier. $\mathrm{K}$ may have been an impure ion introduced during the preparation; the carbon coming from the conductive tape.

$\mathrm{Fe} / \gamma-\mathrm{Al}_{2} \mathrm{O}_{3}$ : An ordinary optical image showed that the sample was orange. In Figure $1 \mathrm{~b}$, fine particles exist on the carrier surface. These particles were successfully loaded and uniformly distributed Fe. The spectra also showed that the sample contained aluminum, oxygen, iron, and carbon. The main components of $\gamma-\mathrm{Al}_{2} \mathrm{O}_{3}$ carrier were aluminum and oxygen. Fe existed as an iron compound loaded on the carrier.

$\mathrm{Fe}-\mathrm{Co} / \gamma-\mathrm{Al}_{2} \mathrm{O}_{3}$ : An ordinary optical image shows that the sample was grayish green. In Figure $1 \mathrm{c}$, the adsorbed particles were smaller than pure loaded iron compounds because loaded cobalt and iron compounds are organically bound to each other; as a result, the crystal morphological structures are changed. The spectra also showed that the sample contains aluminum, oxygen, iron, cobalt, and carbon elements. Among these elements, aluminum and oxygen were the main components of the $\gamma-\mathrm{Al}_{2} \mathrm{O}_{3}$ carrier. Iron and cobalt existed as iron and cobalt compounds loaded on the carrier. 


\subsection{XRD Characterization}

$\gamma-\mathrm{Al}_{2} \mathrm{O}_{3}, \mathrm{Fe} / \gamma-\mathrm{Al}_{2} \mathrm{O}_{3}$, and $\mathrm{Fe}-\mathrm{Co} / \gamma-\mathrm{Al}_{2} \mathrm{O}_{3}$ were characterized using X-ray diffraction to analyze the phase structure and grain sizes of the carriers and catalysts. The diffraction patterns are shown in Figure 2.

Figure 2 shows that the peak shapes of $\gamma-\mathrm{Al}_{2} \mathrm{O}_{3}, \mathrm{Fe} / \gamma-\mathrm{Al}_{2} \mathrm{O}_{3}$, and $\mathrm{Fe}-\mathrm{Co} / \gamma-\mathrm{Al}_{2} \mathrm{O}_{3}$ were similar. Figure 2a shows the XRD pattern of the unloaded $\gamma-\mathrm{Al}_{2} \mathrm{O}_{3}$ carrier. This carrier showed evident diffraction peaks at $2 \theta$ angles of $66.761^{\circ}, 45.788^{\circ}$, and $37.603^{\circ}$, which corresponded to (440), (400), and (311) crystal planes of $\gamma-\mathrm{Al}_{2} \mathrm{O}_{3}$, respectively. The diffraction peaks were weak, and the peak width at half height was large; therefore, the crystal particles of the $\gamma-\mathrm{Al}_{2} \mathrm{O}_{3}$ carriers were small. The patterns of the $\mathrm{Fe} / \gamma-\mathrm{Al}_{2} \mathrm{O}_{3}$ carrier in Figure $1 \mathrm{~b}$ and the $\mathrm{Fe}-\mathrm{Co} / \gamma-\mathrm{Al}_{2} \mathrm{O}_{3}$ carrier in Figure $1 \mathrm{c}$ were compared with the diffraction pattern of the $\gamma-\mathrm{Al}_{2} \mathrm{O}_{3}$ carrier. At similar positions, they all had characteristic $\gamma-\mathrm{Al}_{2} \mathrm{O}_{3}$ diffraction peaks; however, no evident characteristic diffraction peaks of iron or cobalt compounds were observed. SEM results were compared with those of spectroscopy. The loaded iron and cobalt elements showed no characteristic peaks on the XRD pattern, most likely because of the following: (1) the total amount of doped iron and cobalt was low; in addition, the content of each element was $<7 \%$, which is below the detection limit of the XRD instrument; (2) catalysts are prepared using a homogeneous precipitation method, and iron and cobalt compounds were evenly distributed on the carrier surfaces, thereby forming small particles; (3) the formed iron and cobalt compounds were in an amorphous state. By comparison, the characteristic peaks of $\gamma-\mathrm{Al}_{2} \mathrm{O}_{3}$ shifted and widened, particularly at the (311) plane, although no other characteristic crystal peaks were observed in the diffraction patterns of $\mathrm{Fe} / \gamma-\mathrm{Al}_{2} \mathrm{O}_{3}$ or $\mathrm{Fe}-\mathrm{Co} / \gamma-\mathrm{Al}_{2} \mathrm{O}_{3}$ except those of $\gamma-\mathrm{Al}_{2} \mathrm{O}_{3}$. This finding was most likely caused by iron and cobalt doping, which affects the lattice constant of $\gamma-\mathrm{Al}_{2} \mathrm{O}_{3}$. This process results in the lattice distortion of $\gamma-\mathrm{Al}_{2} \mathrm{O}_{3}$ and the shift in the diffraction peak.

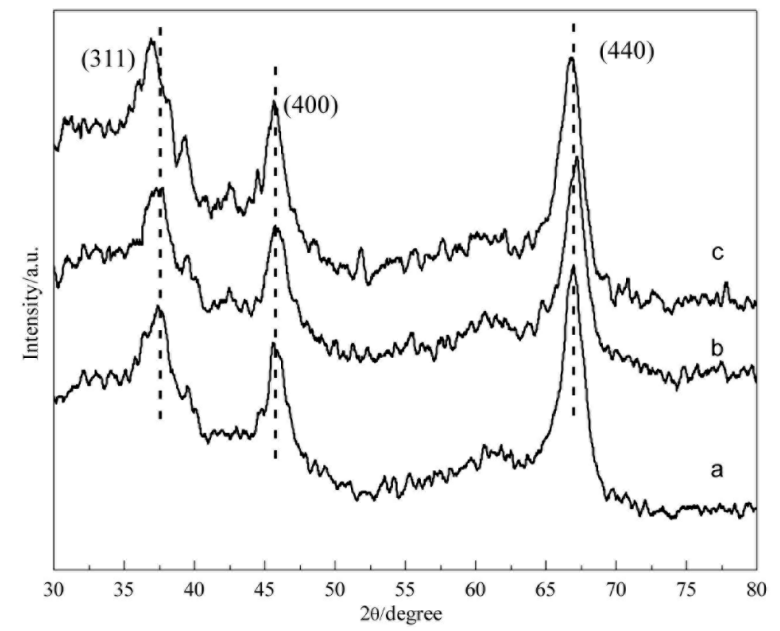

Figure 2. X-ray diffraction patterns of (a) $\gamma-\mathrm{Al}_{2} \mathrm{O}_{3} ;$ (b) $\mathrm{Fe} / \gamma-\mathrm{Al}_{2} \mathrm{O}_{3} ;$ (c) $\mathrm{Fe}-\mathrm{Co} / \gamma-\mathrm{Al}_{2} \mathrm{O}_{3}$.

\subsection{XPS Characterization}

In Figure 2, the diffraction patterns failed to clearly indicate the chemical valence of iron and cobalt compounds loaded on the $\gamma-\mathrm{Al}_{2} \mathrm{O}_{3}$ carrier, although the crystal form changed to a certain degree. Therefore, the chemical states of the constituent elements on the catalyst surface were detected using an X-ray photoelectron spectrometer. The patterns of the full spectrum scanning of $\mathrm{Fe} / \gamma-\mathrm{Al}_{2} \mathrm{O}_{3}$ and $\mathrm{Fe}-\mathrm{Co} / \gamma-\mathrm{Al}_{2} \mathrm{O}_{3}$ catalysts and the high-resolution scanning results of the iron and cobalt compounds are shown in Figures 3 and 4, respectively.

Figure 3 (XPS spectrum of $\mathrm{Fe} / \gamma-\mathrm{Al}_{2} \mathrm{O}_{3}$ ): the patterns of the full spectrum scanning of $\mathrm{Fe} / \gamma-\mathrm{Al}_{2} \mathrm{O}_{3}$ and the high-resolution scanning patterns of the loaded iron compound. At 530.27, 73.2, 284.21, and $710.96 \mathrm{eV}$, the main peaks of $\mathrm{O} 1 \mathrm{~s}, \mathrm{Al} 2 \mathrm{p}, \mathrm{C} 1 \mathrm{~s}$, and Fe2p were observed, respectively. This result 
indicated that the catalyst surface mainly contains three elements—namely, $\mathrm{Fe}, \mathrm{O}$, and $\mathrm{Al}$ - and this finding was consistent with the catalyst preparation and in accordance with the electron energy spectra. Carbon was a calibration element introduced to correct the charging effect in the XPS detection result. The binding energies of Fe2p1/2 and Fe2p3/2 in the inset were located at 724.28 and $710.43 \mathrm{eV}$, respectively. The difference of $13.6 \mathrm{eV}$ between the two peaks and the existence of satellite peaks indicated that the valence of iron in the catalyst is +3 [28-32]. Iron showed a satellite peak with high interference and an Auger peak, which caused difficulty in differentiating the peaks of the binding energy of Fe to identify the types of iron compound in XPS. Thus, the exact state of iron compounds in catalysts could not be determined; as such, other characterization methods should be combined.

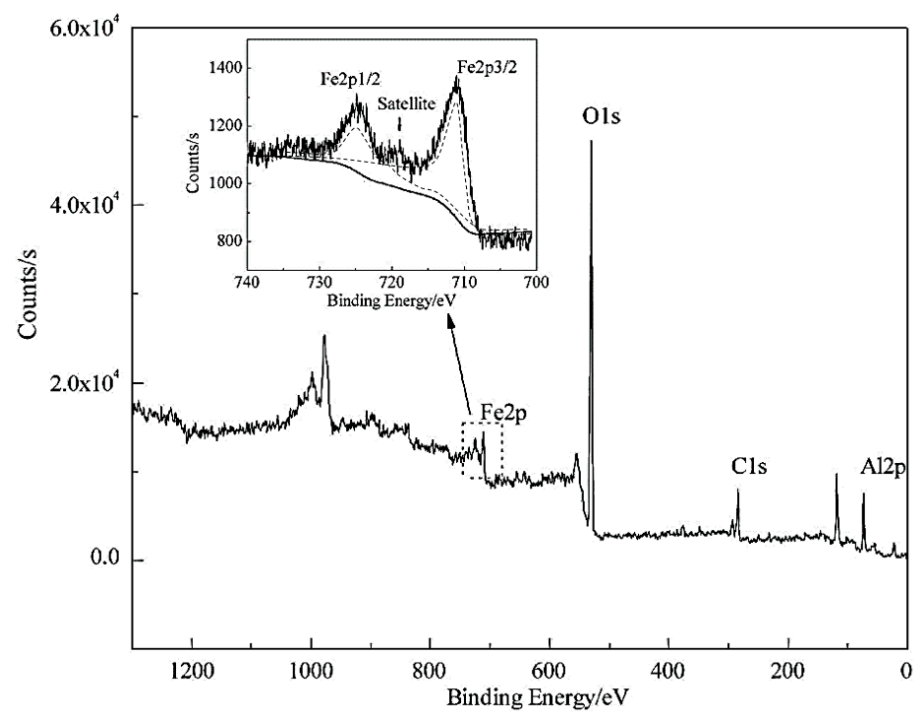

Figure 3. XPS spectrum of $\mathrm{Fe} / \gamma-\mathrm{Al}_{2} \mathrm{O}_{3}$ (inset: high resolution $\mathrm{XPS}$ of $\mathrm{Fe}^{3+}$ ).
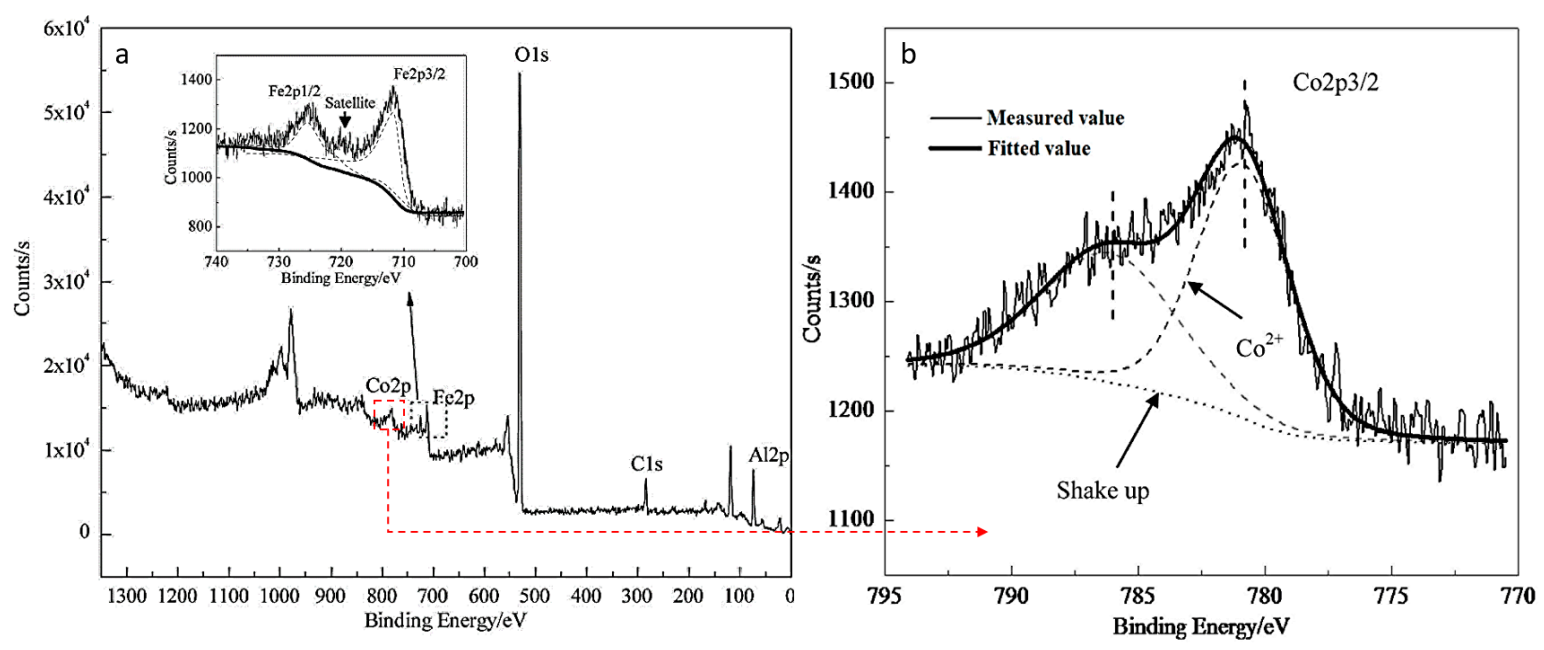

Figure 4. (a) XPS spectrum of $\mathrm{Fe}-\mathrm{Co} / \gamma-\mathrm{Al}_{2} \mathrm{O}_{3}$ (inset: high resolution $\mathrm{XPS}$ of $\mathrm{Fe}^{3+}$ ); (b) High resolution XPS of $\mathrm{Co}^{2+}$.

Figure 4 (XPS spectrum of Fe-Co/ $\gamma-\mathrm{Al}_{2} \mathrm{O}_{3}$ ): the full spectrum scanning pattern of $\mathrm{Fe}-\mathrm{Co} / \gamma-\mathrm{Al}_{2} \mathrm{O}_{3}$ and the high-resolution scanning pattern of the loaded Fe compound. At 530.97, 73.88, 284.49, 711.95, and $779.23 \mathrm{eV}$, the spectral peaks of $\mathrm{O} 1 s, \mathrm{Al} 2 p, \mathrm{C} 1 s, \mathrm{Fe} 2 p$, and $\mathrm{Co} 2 p$ were detected, respectively. This result indicated that the catalyst surface mainly contains four elements-namely, Fe, $\mathrm{O}, \mathrm{Al}$, and Co. This finding is consistent with the catalyst preparation and in accordance with the electron energy spectra. Carbon originated from the calibration element introduced to correct for the charging effect 
in the XPS detection result; this finding is similar to that shown in Figure 5. The binding energies of $\mathrm{Fe} 2 p 1 / 2$ and $\mathrm{Fe} 2 p 3 / 2$ in the inset are located at 724.88 and $711.38 \mathrm{eV}$, respectively. By analyzing Figure 5, the difference of $13.6 \mathrm{eV}$ between the two peaks and the existence of satellite peaks indicated that the valence of iron in the catalyst was +3 . In this way, the existence state of iron compounds in catalysts could not be identified yet.

Figure 4 (XPS spectrum of Co2p region): the high-resolution scanning pattern of the main peak of the Co element in Figure 4. XPSPEAK 4.1 was used to differentiate peaks and resemble Co2p3/2 with a Shirley-type background and $80 \%$ Lorentzian-Gaussian function decomposition. At 780.9 and $786.1 \mathrm{eV}$, the binding energy of $\mathrm{Co}^{2+}$ and the shake-up peak of the divalent cobalt was observed, respectively [33-35]; therefore, cobalt on the surface of $\mathrm{Fe}-\mathrm{Co} / \gamma-\mathrm{Al}_{2} \mathrm{O}_{3}$ mainly exists as $\mathrm{CoO}$ [6,36-40].

\subsection{FT-IR Characterization}

To further investigate the forms of elements on the catalyst surface, $\gamma-\mathrm{Al}_{2} \mathrm{O}_{3}, \mathrm{Fe} / \gamma-\mathrm{Al}_{2} \mathrm{O}_{3}$, and $\mathrm{Fe}-\mathrm{Co} / \gamma-\mathrm{Al}_{2} \mathrm{O}_{3}$ samples were characterized by FT-IR, and the results are shown in Figure 5 .

Figure 5 (from top to bottom) shows the IR patterns of $\gamma-\mathrm{Al}_{2} \mathrm{O}_{3}, \mathrm{Fe} / \gamma-\mathrm{Al}_{2} \mathrm{O}_{3}$, and $\mathrm{Fe}-\mathrm{Co} / \gamma-\mathrm{Al}_{2} \mathrm{O}_{3}$. In Figure 5, three spectral lines exhibited broad absorption peaks at $500 \mathrm{~cm}^{-1}$ to $600 \mathrm{~cm}^{-1}$, which is the stretching vibration peak of the Al-O bond in the catalyst carrier $\gamma-\mathrm{Al}_{2} \mathrm{O}_{3}$. Compared with pure $\gamma-\mathrm{Al}_{2} \mathrm{O}_{3}$ (Figure 5a), synthetic catalysts of $\mathrm{Fe} / \gamma-\mathrm{Al}_{2} \mathrm{O}_{3}$ and $\mathrm{Fe}-\mathrm{Co} / \gamma-\mathrm{Al}_{2} \mathrm{O}_{3}$ exhibited evident absorption peaks at 3444 and $1557 \mathrm{~cm}^{-1}$ to $1410 \mathrm{~cm}^{-1}$, which correspond to the stretching vibration peak and the bending vibration peak of the hydroxyl group, respectively [41-44]. Combined with the presence of the hydroxyl group deformation vibration at $890 \mathrm{~cm}^{-1}$, the absorption peaks at these two positions corresponded to the hydroxyl group on the catalyst surface instead of bound water. The absorption peaks at $1100 \mathrm{~cm}^{-1}$ in Figure $5 \mathrm{a}-\mathrm{c}$ are the stretching vibration peaks of Fe-O [45]. Furthermore, the peaks at $890 \mathrm{~cm}^{-1}$ and $796 \mathrm{~cm}^{-1}$ are considered to be the characteristic absorption peak of $\alpha-\mathrm{FeOOH}[46,47]$.

Based on the XPS characterization results of the catalysts, our conclusion is that Fe is mainly present as $\alpha-\mathrm{FeOOH}$ on the carrier surface.

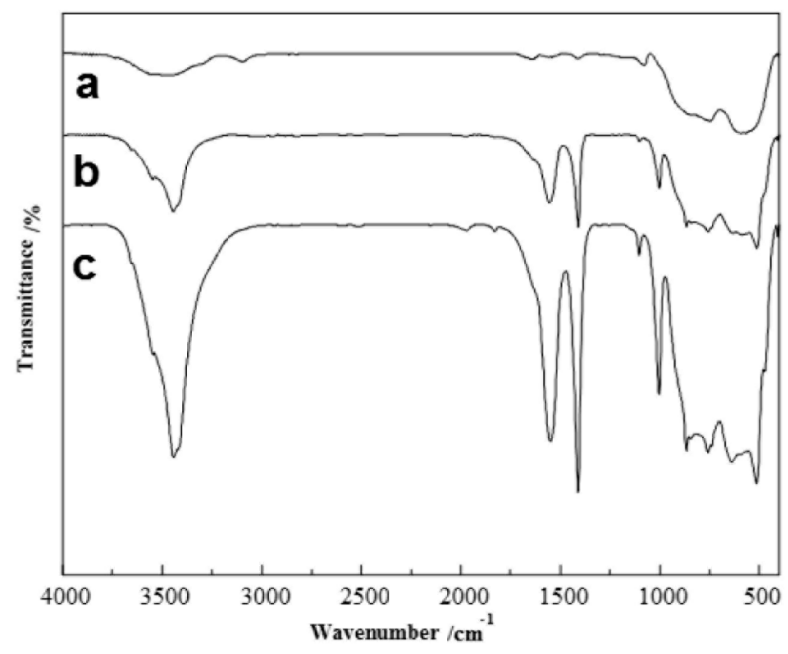

Figure 5. FT-IR spectra of (a) $\gamma-\mathrm{Al}_{2} \mathrm{O}_{3} ;$ (b) $\mathrm{Fe} / \gamma-\mathrm{Al}_{2} \mathrm{O}_{3}$; (c). $\mathrm{Fe}-\mathrm{Co} / \gamma-\mathrm{Al}_{2} \mathrm{O}_{3}$.

\subsection{BET Characterization}

A BET test was performed to investigate the pore size distribution, specific surface area, and porosity changes of the $\gamma-\mathrm{Al}_{2} \mathrm{O}_{3}$ carrier, $\mathrm{Fe} / \gamma-\mathrm{Al}_{2} \mathrm{O}_{3}$ catalyst, and $\mathrm{Fe}-\mathrm{Co} / \gamma-\mathrm{Al}_{2} \mathrm{O}_{3}$ before and after loading. The results of the isothermal adsorption and desorption test of the $\mathrm{Fe}-\mathrm{Co} / \gamma-\mathrm{Al}_{2} \mathrm{O}_{3}$ catalyst are shown in Figure 6. 
Figure 6 shows that between the relative pressures (specific pressure area) $\left(\mathrm{P} / \mathrm{P}_{0}\right) 0.6$ and 0.9 , the adsorption-desorption isotherm showed an evident hysteresis loop, which is a type IV isotherm. This finding indicates that $\mathrm{Fe}-\mathrm{Co} / \gamma-\mathrm{Al}_{2} \mathrm{O}_{3}$ catalyst contains a porous structure. The adsorption curve was almost perpendicular to the hysteresis loop, and the relative pressure of condensation and evaporation was found near the center. According to the definition of IUPAC [48], this loop is classified as a type $\mathrm{H} 1$ hysteresis loop; in addition, a porous material with this type of hysteresis loop generally contains a cylindrical hole opening at both ends.

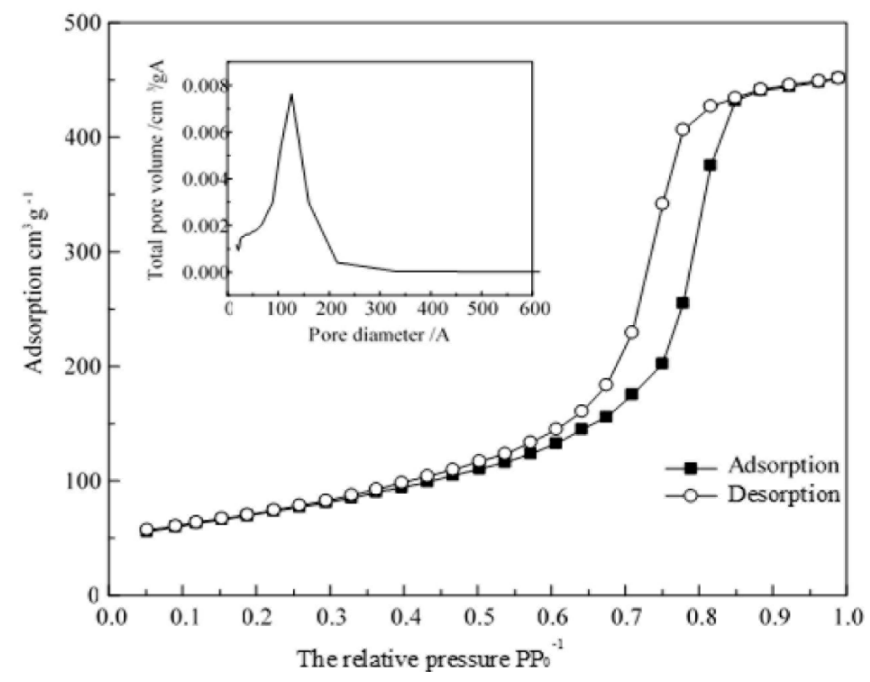

Figure 6. Nitrogen adsorption/desorption isotherms of $\gamma-\mathrm{Al}_{2} \mathrm{O}_{3}$ (inset shows pore diameter distribution).

The inset in Figure 6 shows the pore size distribution curve. From the inset, we found that the $\mathrm{BJH}$ pore size distribution of the $\mathrm{Fe}-\mathrm{Co} / \gamma-\mathrm{Al}_{2} \mathrm{O}_{3}$ catalyst can be determined with a pore size of $105 \AA$ to $145 \AA$.

The BET tests of $\gamma-\mathrm{Al}_{2} \mathrm{O}_{3}$ carrier, $\mathrm{Fe} / \gamma-\mathrm{Al}_{2} \mathrm{O}_{3}$ catalyst, and $\mathrm{Fe}-\mathrm{Co} / \gamma-\mathrm{Al}_{2} \mathrm{O}_{3}$ catalyst revealed the BET specific surface area, total pore volume, and average pore diameter (Table 2).

Table 2. BET test results of $\gamma-\mathrm{Al}_{2} \mathrm{O}_{3} \mathrm{Fe} / \gamma-\mathrm{Al}_{2} \mathrm{O}_{3}$ and $\mathrm{Fe}-\mathrm{Co} / \gamma-\mathrm{Al}_{2} \mathrm{O}_{3}$ particles.

\begin{tabular}{cccc}
\hline & BET Specific Surface Area $\left(\mathbf{m}^{\mathbf{2}} \mathbf{g}^{-\mathbf{1}}\right)$ & Total Pore Volume $\left(\mathbf{m L ~}^{-\mathbf{1}}\right)$ & Average Pore Diameter (A) \\
\hline$\gamma-\mathrm{Al}_{2} \mathrm{O}_{3}$ & 214.6 & 0.7 & 116.4 \\
$\mathrm{Fe} / \gamma-\mathrm{Al}_{2} \mathrm{O}_{3}$ & 213.1 & 0.6 & 115.3 \\
$\mathrm{Fe}-\mathrm{Co} / \gamma-\mathrm{Al}_{2} \mathrm{O}_{3}$ & 214.0 & 0.6 & 115.7 \\
\hline
\end{tabular}

Compared with the $\gamma-\mathrm{Al}_{2} \mathrm{O}_{3}$ carrier, the specific surface area of the $\mathrm{Fe} / \gamma-\mathrm{Al}_{2} \mathrm{O}_{3}$ catalyst and the $\mathrm{Fe}-\mathrm{Co} / \gamma-\mathrm{Al}_{2} \mathrm{O}_{3}$ catalyst loaded with the active components changes from $214.636 \mathrm{~m}^{2} \mathrm{~g}^{-1}$ to 213.0517 and $213.9581 \mathrm{~m}^{2} \mathrm{~g}^{-1}$, respectively (Table 2). The total pore volume changed from $0.652486 \mathrm{~mL}$ $\mathrm{g}^{-1}$ to 0.641361 and $0.645537 \mathrm{~mL} \mathrm{~g}^{-1}$, respectively; the average pore size changes from $116.3518 \AA$ to 115.2651 and $115.6964 \AA$, respectively. Although there were certain absolute changes, considering the relative change rate and errors, we believed that active components do not evidently influence the pore structure of the original carrier. On the one hand, this was because the total load is low; on the other hand, the active component in the carrier surface was evenly distributed. The BET test result showed that synthetic catalysts exhibit a large specific surface area and a uniform pore size distribution (Figure 6 and Table 2).

\subsection{XRF Characterization}

XRF was performed to quantitatively analyze the calibration curves of metal/alloy elements in each constituent of the $\mathrm{Fe} / \gamma-\mathrm{Al}_{2} \mathrm{O}_{3}$ and $\mathrm{Fe}-\mathrm{Co} / \gamma-\mathrm{Al}_{2} \mathrm{O}_{3}$ catalysts to determine the real loading 
amounts of the active components in the $\mathrm{Fe} / \gamma-\mathrm{Al}_{2} \mathrm{O}_{3}$ and $\mathrm{Fe}-\mathrm{Co} / \gamma-\mathrm{Al}_{2} \mathrm{O}_{3}$ catalysts. Table 3 shows that the mass fraction of the $\mathrm{Fe}$ active component was $5.38 \%$ in the $\mathrm{Fe} / \gamma-\mathrm{Al}_{2} \mathrm{O}_{3}$ catalyst; by contrast, the mass fractions of the $\mathrm{Fe}$ and $\mathrm{Co}$ active components in the $\mathrm{Fe}-\mathrm{Co} / \gamma-\mathrm{Al}_{2} \mathrm{O}_{3}$ catalyst were $2.76 \%$ and $2.82 \%$, respectively; this finding is roughly consistent with the impregnation ratio.

Table 3. Catalyst component.

\begin{tabular}{cccccccc}
\hline & Component & Al & O & Fe & Co & Ca & Na \\
\hline \multirow{2}{*}{ The mass fractions $(\%)$} & $\mathrm{Fe} / \gamma-\mathrm{Al}_{2} \mathrm{O}_{3}$ & 51.61 & 42.91 & 5.38 & 0 & 0.037 & 0.026 \\
& $\mathrm{Fe}-\mathrm{Co} / \gamma-\mathrm{Al}_{2} \mathrm{O}_{3}$ & 51.27 & 43.06 & 2.76 & 2.82 & 0.031 & 0.029 \\
\hline
\end{tabular}

\section{Experiment on the Heterogeneous Fenton Treatment of Coalbed Methane-Produced Water in Backflow Stage}

\subsection{Effect of Coalbed Methane-Produced Water Treatment}

Analysis of the experimental data determined the effects of the catalyst carrier adsorption on $\mathrm{COD}_{\mathrm{Cr}}$ in the effluent from the coagulation-pretreated coalbed methane-produced water in the backflow stage, the direct oxidative degradation with $\mathrm{H}_{2} \mathrm{O}_{2}$ for $\mathrm{COD}_{\mathrm{Cr}}$, and catalytic oxidation degradation of the catalyst $/ \mathrm{H}_{2} \mathrm{O}_{2}$ system for $\mathrm{COD}$ Cr. Water quality after coagulation-flocculation is shown in Table 4. The experimental conditions were as follows: $25^{\circ} \mathrm{C}, \mathrm{pH} 5.1$ (raw water unadjusted), $368 \mathrm{mg} \mathrm{L}^{-1} \mathrm{COD}_{\mathrm{Cr}} ; \mathrm{H}_{2} \mathrm{O}_{2}$ concentration was twice the theoretical amount, which was $40 \mathrm{mmol} \mathrm{L}^{-1}$; catalyst concentration of $4 \mathrm{~g} \mathrm{~L}^{-1}$ was calculated according to the molar ratio of the active component to $\mathrm{H}_{2} \mathrm{O}_{2}(1: 10)$. The experimental result is shown in Figure 7.

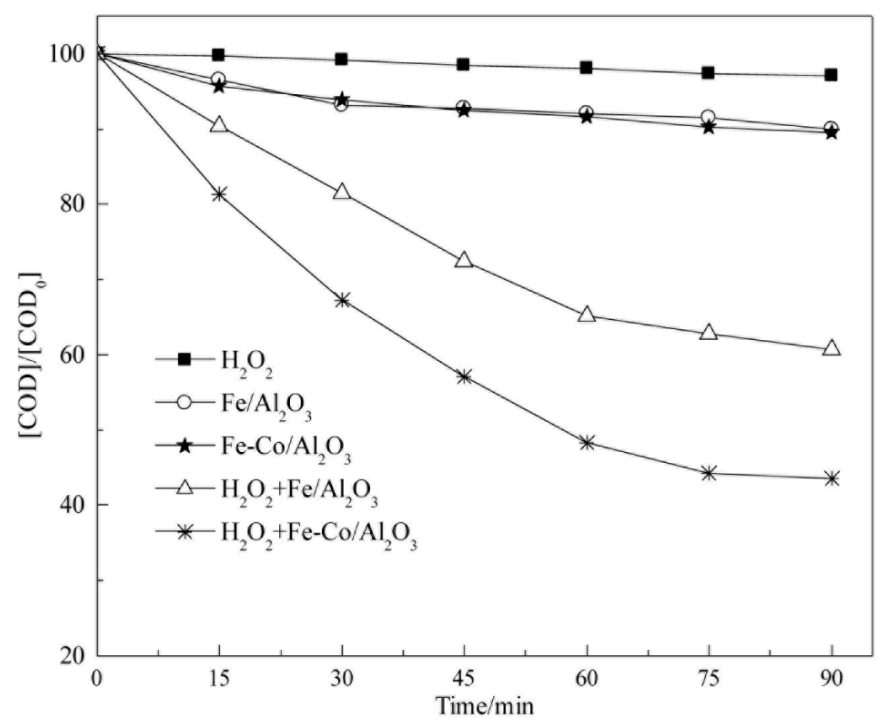

Figure 7. Degradation of curves under different conditions.

Table 4. Water quality after coagulation-flocculation.

\begin{tabular}{cccccc}
\hline Index & PH & COD $_{\mathrm{Cr}}\left(\mathrm{mg} \mathrm{L}^{-\mathbf{1}}\right)$ & Turbidity (NTU) & Fluorine $_{\left(\mathrm{mg} \mathrm{L}^{-\mathbf{1}}\right)}$ & TDS $_{\left(\mathbf{m g ~ L}^{-1}\right)}$ \\
\hline 5.1 & 368 & 31 & 4.7 & 4751 \\
\hline
\end{tabular}

Figure 7 shows that $2.7 \% \mathrm{COD}_{\mathrm{Cr}}$ was removed in $90 \mathrm{~min}$ when $\mathrm{H}_{2} \mathrm{O}_{2}$ as the only oxidant existed in the system. This finding was possible because the oxidation potentials of $\mathrm{H}_{2} \mathrm{O}_{2}$ and $\mathrm{HO} \bullet$ were 1.776 and $2.85 \mathrm{~V}$, respectively; this result indicated that direct oxidation of $\mathrm{H}_{2} \mathrm{O}_{2}$ is significantly lower than that of $\mathrm{HO} \bullet$. 
If a catalyst exists in the system, either $\mathrm{Fe} / \mathrm{Al}_{2} \mathrm{O}_{3}$ or $\mathrm{Fe}-\mathrm{Co} / \mathrm{Al}_{2} \mathrm{O}_{3}$, the removal rate of $\mathrm{COD}_{\mathrm{Cr}}$ reaches approximately $10 \%$ in $90 \mathrm{~min}$. As discussed in Section 3.5, synthetic $\mathrm{Fe} / \mathrm{Al}_{2} \mathrm{O}_{3}$ and $\mathrm{Fe}-\mathrm{Co} / \mathrm{Al}_{2} \mathrm{O}_{3}$ catalysts contained a large specific surface area and a large pore volume, thereby adsorbing organic compounds in coalbed methane-produced water. The specific surface areas of synthetic $\mathrm{Fe} / \mathrm{Al}_{2} \mathrm{O}_{3}$ and $\mathrm{Fe}-\mathrm{Co} / \mathrm{Al}_{2} \mathrm{O}_{3}$ catalysts, which are 213.0517 and $213.9581 \mathrm{~m}^{2} \mathrm{~g}^{-1}$, respectively, slightly differed. Therefore, the corresponding removal rates are comparable. A heterogeneous Fenton reaction is a surface reaction, and its reaction mechanism is as follows: $\mathrm{H}_{2} \mathrm{O}_{2}$ is first adsorbed on a catalyst surface and then reacts with this catalyst to form a complex. This complex subsequently reacts with a catalytic active component to generate $\mathrm{HO} \bullet$; this complex further reacts with reactant molecules adsorbed onto a catalyst surface. Hence, a catalyst can catalyze a reaction only when this catalyst exhibits chemical adsorption ability on reactant molecules. Therefore, chemical adsorption is an important condition in a catalytic action. This experiment indicated that synthetic $\mathrm{Fe} / \mathrm{Al}_{2} \mathrm{O}_{3}$ and $\mathrm{Fe}-\mathrm{Co} / \mathrm{Al}_{2} \mathrm{O}_{3}$ catalysts can absorb organic compounds in coalbed methane-produced water; this ability is a premise of a heterogeneous Fenton reaction.

$\mathrm{COD}_{\mathrm{Cr}}$ is removed effectively when a catalyst and an oxidant are present in a system. The removal rates of $\mathrm{H}_{2} \mathrm{O}_{2}+\mathrm{Fe} / \mathrm{Al}_{2} \mathrm{O}_{3}$ and $\mathrm{H}_{2} \mathrm{O}_{2}+\mathrm{Fe}-\mathrm{Co} / \mathrm{Al}_{2} \mathrm{O}_{3}$ systems in 90 min were $39.3 \%$ and $56.4 \%$, respectively. The latter was apparently better than the former because of $\mathrm{Co}^{2+}$ doping. $\mathrm{Co}^{2+}$, as a transition metal, exhibits a similar property to $\mathrm{Fe}^{2+}$ and can react with $\mathrm{H}_{2} \mathrm{O}_{2}$ to generate $\mathrm{HO} \bullet$ [49], as shown in Equation (2). Moreover, $\mathrm{Co}^{2+}$ and $\mathrm{Fe}^{3+}$ doping can result in a redox reaction with each other; as a result, electron transfer is promoted, and the conversion cycle between metals with different valences is accelerated [50,51], as shown in Equation (3). As a result, catalytic efficiency is improved

$$
\begin{gathered}
\mathrm{Co}^{2+}+\mathrm{H}_{2} \mathrm{O}_{2} \rightarrow \mathrm{Co}^{3+}+\mathrm{HO} \bullet+\mathrm{OH}^{-} \\
\mathrm{Fe}^{2+}+\mathrm{Co}^{3+} \rightarrow \mathrm{Fe}^{3+}+\mathrm{Co}^{2+}
\end{gathered}
$$

Thus, the following discussion focuses on the $\left(\mathrm{H}_{2} \mathrm{O}_{2}+\mathrm{Fe}-\mathrm{Co} / \mathrm{Al}_{2} \mathrm{O}_{3}\right)$ system.

\subsection{Influence of Initial $p H$}

Solution $\mathrm{pH}$ is an essential factor that affects the degradation efficiency of organic pollutants. This study discussed the influence of different initial $\mathrm{pH}$ values of effluent from coagulation-pretreated coalbed methane-produced water in backflow stage on a heterogeneous Fenton reaction. The experimental conditions were as follows: $25^{\circ} \mathrm{C} ; \mathrm{H}_{2} \mathrm{O}_{2}$ concentration of $40 \mathrm{mmol} \mathrm{L}^{-1}$; catalyst concentration of $4 \mathrm{~g} \mathrm{~L}^{-1}$; and initial $\mathrm{pH}$ values of 2.5, 3.5, 5.1 (raw water), 6, and 7, respectively. The experimental results are shown in Figure 8.

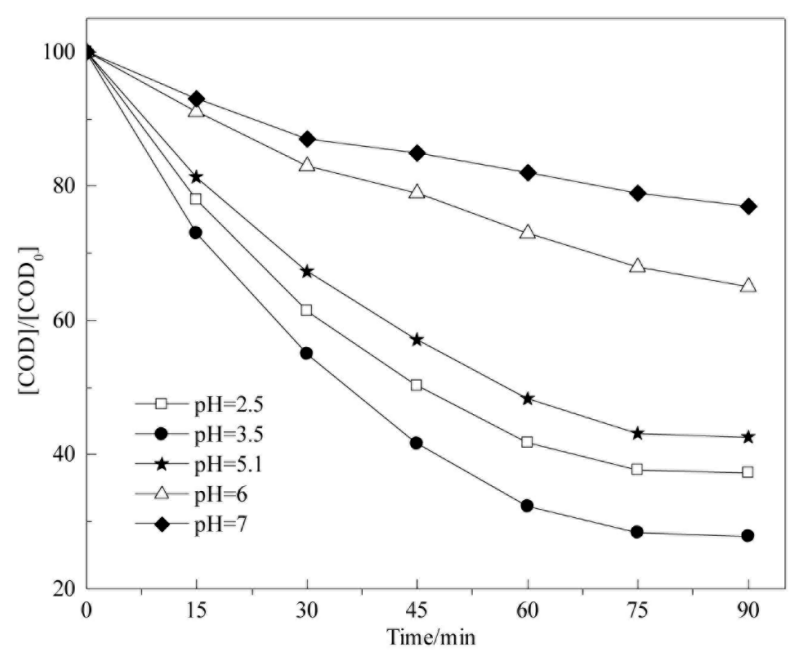

Figure 8. Influence of different initial $\mathrm{pH}$ values. 
Figure 8 shows that the highest removal efficiency of $\mathrm{COD}_{\mathrm{Cr}}$ was obtained when $\mathrm{pH}$ was 3.5, and the removal rate reached $72.2 \%$ in $90 \mathrm{~min}$. This finding was consistent with an optimal $\mathrm{pH}$ range of 2 to 4 [52]. The removal rate of $\mathrm{COD}_{\mathrm{Cr}}$ reached $57.4 \%$ when the $\mathrm{pH}$ of raw water was 5.1. $\mathrm{pH}$ is one of the most important limiting factors of large-scale industrial applications in a conventional homogeneous Fenton reaction. According to Haber-Weiss cycle theory [29,30,53], a Fenton reaction under an alkaline condition proceeds very slowly to the left, as shown in Equation (4). In a conventional homogeneous Fenton reaction, the catalyst is in an ionic form, which can easily form insoluble hydroxides in an alkaline environment; this process subsequently weakens catalysis.

$$
\mathrm{Fe}^{2+}+\mathrm{H}_{2} \mathrm{O}_{2} \rightarrow \mathrm{Fe}^{3+}+\mathrm{OH}^{-}+\mathrm{HO} \bullet
$$

It is acknowledged that the heterogeneous Fenton reaction is less affected by $\mathrm{pH}$ than the traditional homogeneous Fenton reaction [54,55]. Therefore, HO• generation is affected only to a small degree. However, $\mathrm{pH}$ can affect a heterogeneous Fenton reaction as a surface reaction by altering the surface properties of catalysts [56] and adsorption model of reactants on a catalyst surface [57].

This experiment indicates that $\mathrm{pH}$ affects a heterogeneous Fenton reaction; however the $\mathrm{COD}_{\mathrm{Cr}}$ removal rate also reaches $57.4 \%$ when the $\mathrm{pH}$ is 5.1.Thus, the heterogeneous Fenton reaction is affected by $\mathrm{pH}$. This reaction is not fully sustained; thus, a changing $\mathrm{pH}$ during this reaction should be detected. Figure 9 shows the change in $\mathrm{pH}$ in a heterogeneous Fenton reaction of effluent from coagulation-pretreated coalbed methane-produced water in backflow stage.

Figure 9 shows that the $\mathrm{pH}$ of treated water decreased to a $\mathrm{pH}$ value in a short time and stabilized in that value as the reaction proceeded. This finding was possible because organic acids accumulate in raw water where large molecules of organic matter are converted into smaller molecules. However, a solution of organic acids, such as acetic acid, yielded $\mathrm{pH}$ values ranging from 4.0 to 5.0. As the reaction proceeded, the solution $\mathrm{pH}$ reached 4.0 to 5.0. In catalytic oxidation during a heterogeneous Fenton reaction, active components were well dispersed on the $\mathrm{Al}_{2} \mathrm{O}_{3}$ surface. In a solution with a high initial $\mathrm{pH}$, no flocculation occurred; therefore, this compound can initiate a catalytic oxidation reaction. Once the reaction starts, organic acid accumulation can increase the $\mathrm{pH}$ from 4.0 to 6.0; this finding shows that a heterogeneous Fenton reaction elicits a treatment effect on acidic and alkaline environments. In catalytic oxidation during a conventional Fenton reaction, active ions are converted to insoluble hydroxide precipitate in an alkaline solution, resulting in low catalytic oxidation efficiency.

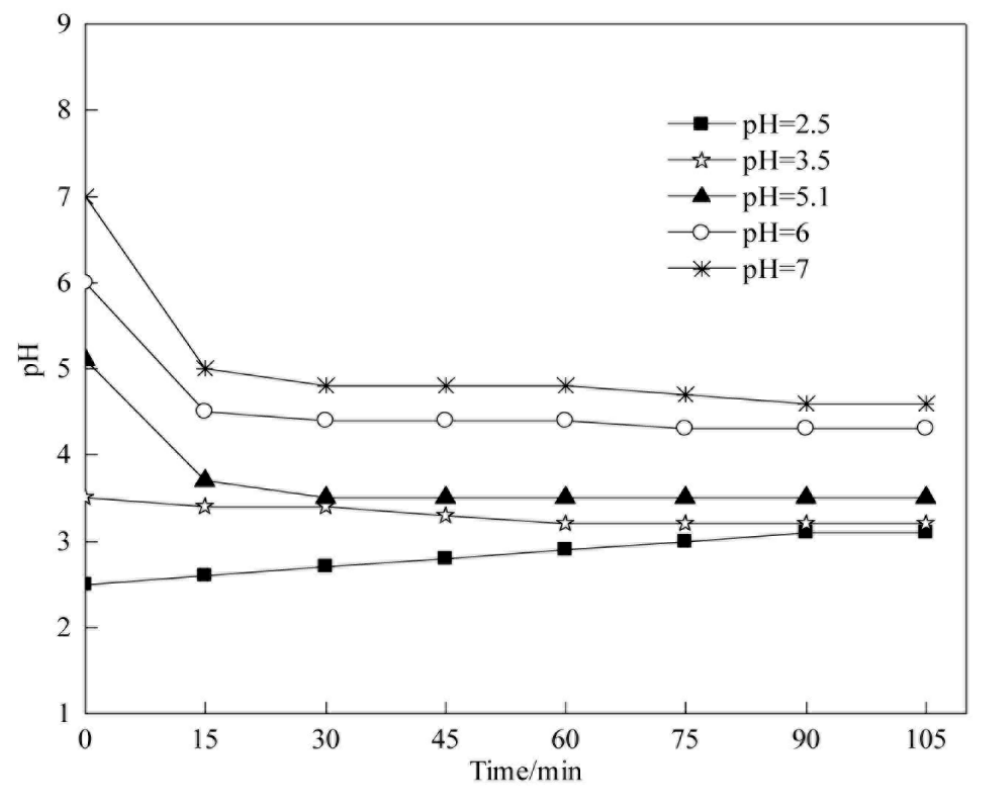

Figure 9. Changes in $\mathrm{pH}$ in the reaction. 


\subsection{Influence of Hydrogen Peroxide Concentration}

As an oxidant, $\mathrm{H}_{2} \mathrm{O}_{2}$ generates the $\mathrm{HO} \bullet$ precursor in a conventional Fenton system. $\mathrm{H}_{2} \mathrm{O}_{2}$ concentration directly affects $\mathrm{HO} \bullet$ production, which further influences oxidation efficiency. In a heterogeneous Fenton system, $\mathrm{H}_{2} \mathrm{O}_{2}$ decomposes to yield $\mathrm{HO} \bullet$, which degrades organic pollutants through the catalytic effect of active components in a solid catalyst. This study described the effect of $\mathrm{H}_{2} \mathrm{O}_{2}$ concentration in effluent from coagulation-pretreated coalbed methane-produced water in backflow stage during a heterogeneous Fenton reaction. The experimental conditions were as follows: $25^{\circ} \mathrm{C}$, initial $\mathrm{pH}$ of 5.1 (raw water), a catalyst concentration of $4 \mathrm{~g} \mathrm{~L}^{-1}$, and $\mathrm{H}_{2} \mathrm{O}_{2}$ concentrations of $10,20,30,40$, and $50 \mathrm{mmol} \mathrm{L}^{-1}$, respectively. The experimental result is shown in Figure 10. The concentration of $\mathrm{H}_{2} \mathrm{O}_{2}$ was selected based on a previous reference [52].

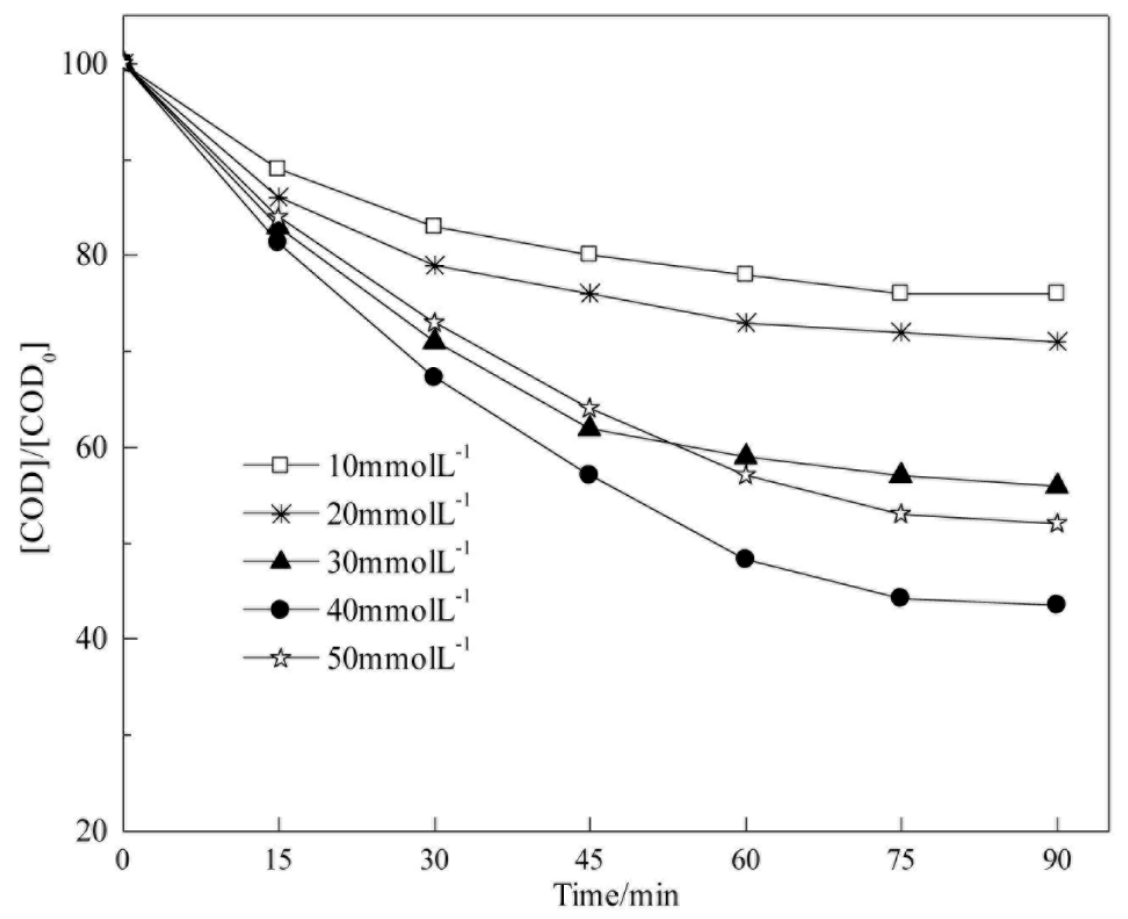

Figure 10. Effect of $\mathrm{H}_{2} \mathrm{O}_{2}$ concentration.

Figure 10 shows that the removal rate of $\mathrm{COD}_{\mathrm{Cr}}$ increases from $24.3 \%$ to $56.8 \%$ in 90 min under experimental conditions when the $\mathrm{H}_{2} \mathrm{O}_{2}$ concentration increases from $10 \mathrm{mmol} \mathrm{L}^{-1}$ to $40 \mathrm{mmol} \mathrm{L}^{-1}$. In a Fenton system, the removal rate of $\mathrm{COD}_{\mathrm{Cr}}$ relies on $\mathrm{HO} \bullet$ generation; in a certain range, the concentration of the generated $\mathrm{HO} \bullet$ is proportional to $\mathrm{H}_{2} \mathrm{O}_{2}$ concentration. Thus, an increase in $\mathrm{H}_{2} \mathrm{O}_{2}$ concentration likely improves $\mathrm{COD}_{\mathrm{Cr}}$ removal. If the $\mathrm{H}_{2} \mathrm{O}_{2}$ concentration is very high, this parameter does not contribute to $\mathrm{COD}_{\mathrm{Cr}}$ removal. The removal rate of $\mathrm{COD}_{\mathrm{Cr}}$ decreases to $47.8 \%$ when the $\mathrm{H}_{2} \mathrm{O}_{2}$ dosage increases to $50 \mathrm{mmol} \mathrm{L}^{-1}$. This is because $\mathrm{H}_{2} \mathrm{O}_{2}$ can eliminate $\mathrm{HO} \bullet$ radicals [58]. The reactions in Equations (5) and (6) occur when the $\mathrm{H}_{2} \mathrm{O}_{2}$ concentration is very high:

$$
\begin{gathered}
\mathrm{H}_{2} \mathrm{O}_{2}+\mathrm{HO} \bullet \rightarrow \mathrm{HO}_{2} \bullet+\mathrm{H}_{2} \mathrm{O} \\
\mathrm{HO}_{2} \bullet+\mathrm{HO} \bullet \rightarrow \mathrm{H}_{2} \mathrm{O}+\mathrm{O}_{2}
\end{gathered}
$$

At this point, $\mathrm{H}_{2} \mathrm{O}_{2}$ competes with organic compounds in coalbed methane-produced water to bind to $\mathrm{HO} \bullet$. The oxidizing ability of $\mathrm{HO}_{2} \bullet$ is not as strong as $\mathrm{HO} \bullet$ [59]; as a result, the removal rate of $\mathrm{COD}_{\mathrm{Cr}}$ decreases. 


\subsection{Influence of Catalyst Dosage}

Catalyst concentration is also an important factor that affects a heterogeneous Fenton reaction. This study described the influence of the catalyst concentration in the effluent from coagulation-pretreated coalbed methane-produced water in the backflow stage during a heterogeneous Fenton reaction. The experimental conditions were as follows: $25^{\circ} \mathrm{C}, \mathrm{H}_{2} \mathrm{O}_{2}$ concentration of $40 \mathrm{mmol} \mathrm{L}-1$, initial $\mathrm{pH}$ of 5.1 (raw water), and catalyst concentrations of $0.5,1,2,4$, and $8 \mathrm{~g} \mathrm{~L}^{-1}$, respectively. The experimental results are shown in Figure 11.

Figure 11 shows that the $\mathrm{COD}_{\mathrm{Cr}}$ removal rate increased from $25.7 \%$ to $57.8 \%$ in $90 \mathrm{~min}$ as the catalyst concentration increased from $0.5 \mathrm{~g} \mathrm{~L}^{-1}$ to $4 \mathrm{~g} \mathrm{~L}^{-1}$. In a heterogeneous Fenton reaction, $\mathrm{HO} \bullet$ is generated by the reaction between $\mathrm{H}_{2} \mathrm{O}_{2}$ and active components; this reaction mainly occurs on the active sites of a catalyst surface according to active site theory [60]. If a catalyst structure remains unchanged, the number of active sites mainly depends on catalyst concentration. With a low dosage, the number of active sites on a catalyst surface is low and inadequate to promote a reaction; therefore, the removal rate of $\mathrm{COD}_{\mathrm{Cr}}$ is low. A large amount of $\mathrm{HO} \bullet$ causes a side reaction, as shown in Equation (7), when the catalyst concentration exceeds the optimal level. $\mathrm{HO} \bullet$ is quenched because of the additional reaction. Thus, $\mathrm{HO} \bullet$ utilization efficiency and $\mathrm{COD}_{\mathrm{Cr}}$ removal rate are reduced. In the experiment, the $\mathrm{COD}_{\mathrm{Cr}}$ removal rate decreased to $51.6 \%$ when the catalyst concentration reached $8 \mathrm{~g} \mathrm{~L}^{-1}$.

$$
2 \mathrm{HO} \bullet \rightarrow \mathrm{H}_{2} \mathrm{O}_{2}
$$

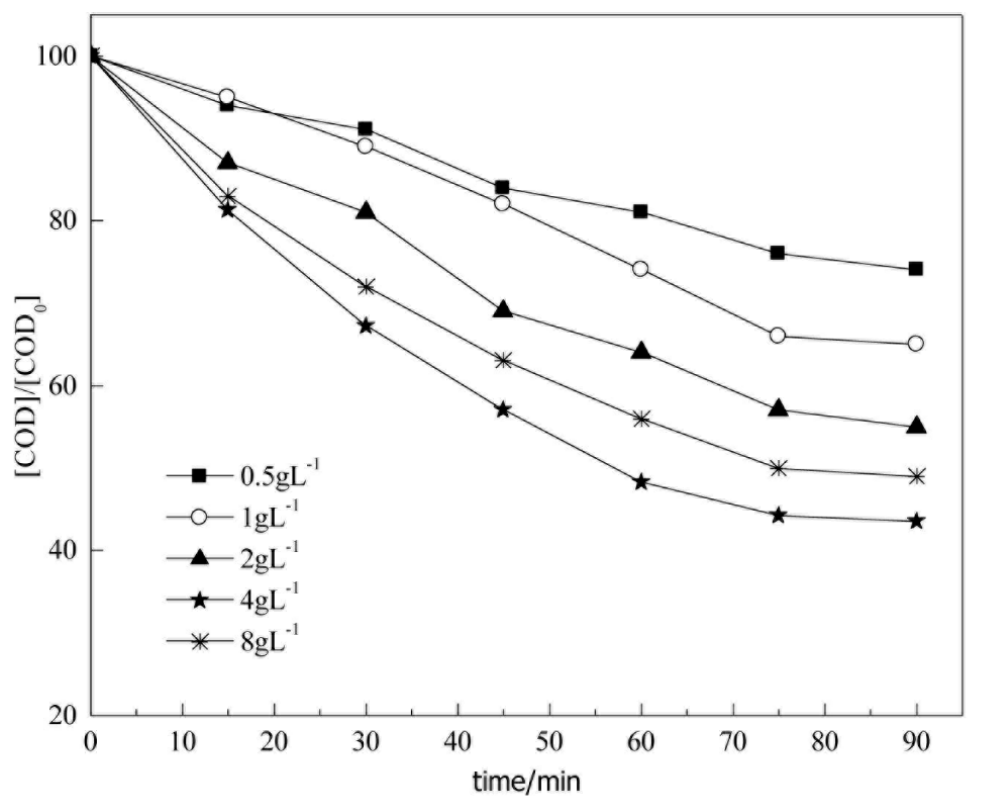

Figure 11. Effects of iron ion concentration.

\subsection{Catalyst Stability}

Catalyst reusability or stability is an important indicator used to evaluate catalyst quality. This study also demonstrated the catalytic performance and dissolution of the active components of the $\mathrm{Fe}-\mathrm{Co} / \mathrm{Al}_{2} \mathrm{O}_{3}$ catalyst after this substance was repeatedly used. The experimental conditions were as follows: $25^{\circ} \mathrm{C}, \mathrm{H}_{2} \mathrm{O}_{2}$ concentration of $40 \mathrm{mmol} \mathrm{L}^{-1}$, initial $\mathrm{pH}$ of 5.1 (raw water), and a catalyst concentration of $4 \mathrm{~g} \mathrm{~L}^{-1}$. The effluent from coagulation-pretreated coalbed methane-produced water in backflow stage was catalytically oxidized for $90 \mathrm{~min}$. The $\mathrm{COD}_{\mathrm{Cr}}$ removal rate was detected, and the reaction solution was filtered through a $0.45 \mu \mathrm{m}$ membrane. The amount of iron and cobalt ions in the filtrate was determined. The filtered catalyst was dried for $1 \mathrm{~h}$ at $105^{\circ} \mathrm{C}$ and subsequently reused five times. The results are shown in Figure 12. 
Figure 12 shows that the $\mathrm{Fe}-\mathrm{Co} / \mathrm{Al}_{2} \mathrm{O}_{3}$ catalytic activity is slightly reduced as reuse time increases. This parameter decreases from $57.8 \%$ in the first usage to $52.7 \%$ in the second usage; catalytic activity is then stabilized at approximately $51 \%$ in the last three usages. Therefore, considering the same reaction time (90 $\mathrm{min}$ ) in each testing experiment, it can be inferred that the oxidation rate is slightly decreased.

During the reuse of the $\mathrm{Fe}-\mathrm{Co} / \mathrm{Al}_{2} \mathrm{O}_{3}$ catalyst, a specific amount of active components is filtered. In the first reuse, the amount of $\mathrm{Fe}+\mathrm{Co}$ lost through filtration is $0.7 \mathrm{mg} \mathrm{L}^{-1}$. The amounts of loss were recorded as $0.8,0.5$, and $0.2 \mathrm{mg} \mathrm{L}^{-1}$ in a small amount at each time when an active component is removed. The results show that the prepared $\mathrm{Fe}-\mathrm{Co} / \mathrm{Al}_{2} \mathrm{O}_{3}$ catalyst is stable and reusable in the experiment.

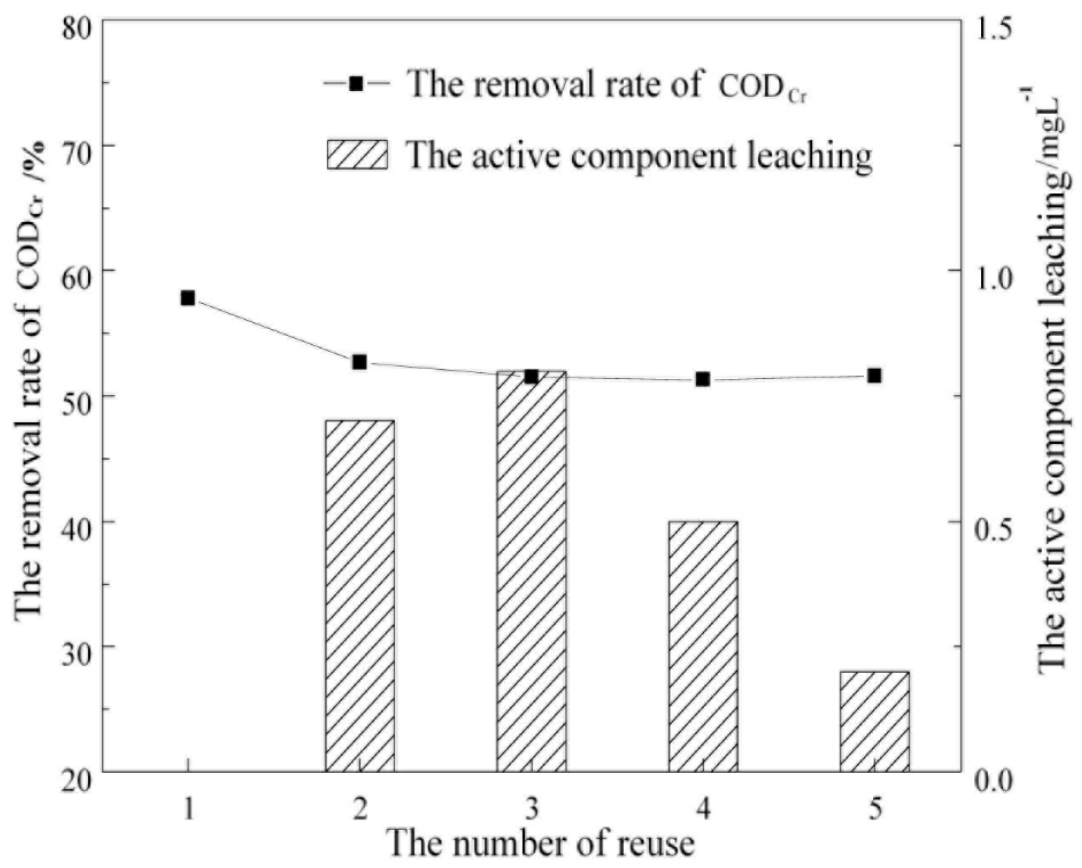

Figure 12. $\mathrm{COD}_{\mathrm{Cr}}$ removal efficiency and metal ions leaching during catalyst recycling.

\section{Reaction Kinetics}

Coalbed methane-produced water in the backflow stage contains a complex composition; therefore, the degradation mechanism via Fenton reaction is also complicated. Organic compounds in coalbed methane-produced water are rich in organic matter, and reaction mechanisms in the Fenton treatment of coalbed methane-produced water are also complex. Thus, the elementary reaction is not easily determined. It is not necessary to clarify the reaction process of each element from the point of water treatment and reuse; we only need to determine the reaction kinetics of $\mathrm{COD}_{\mathrm{Cr}}$ degradation in coalbed methane-produced water during Fenton catalytic oxidation.

In a heterogeneous Fenton system, organic compounds can be directly oxidized by $\mathrm{H}_{2} \mathrm{O}_{2}$ and $\mathrm{HO} \bullet$ generated through $\mathrm{H}_{2} \mathrm{O}_{2}$ decomposition. This reaction is shown in Equations (8) and (9).

$$
\begin{aligned}
& \mathrm{COD}_{\mathrm{Cr}}+\mathrm{H}_{2} \mathrm{O}_{2} \rightarrow \text { Product } \\
& \mathrm{COD}_{\mathrm{Cr}}+\mathrm{HO} \bullet \rightarrow \text { Product }
\end{aligned}
$$

The $\mathrm{COD}_{\mathrm{Cr}}$ degradation rate can be expressed as follows:

$$
\frac{\mathrm{d}\left[\mathrm{COD}_{\mathrm{Cr}}\right]}{\mathrm{dt}}=\mathrm{K}_{\mathrm{H}_{2} \mathrm{O}_{2}}\left[\mathrm{H}_{2} \mathrm{O}_{2}\right]\left[\mathrm{COD}_{\mathrm{cr}}\right]+\mathrm{k}_{\mathrm{HO} \bullet}\left[\mathrm{COD}_{\mathrm{Cr}}\right]
$$

where $\left[\mathrm{COD}_{\mathrm{Cr}}\right]$ is the $\mathrm{COD}_{\mathrm{Cr}}$ concentration at time $t, \mathrm{mg} \mathrm{L}^{-1} ; t$ is the reaction time, $\mathrm{s} ;\left[\mathrm{H}_{2} \mathrm{O}_{2}\right]$ is the mass fraction of $\mathrm{H}_{2} \mathrm{O}_{2}$ at time $t, \mathrm{mg} \mathrm{L}^{-1} ;[\mathrm{HO} \bullet]$ is the mass concentration of $\mathrm{HO} \bullet$ at time $t, \mathrm{mg} \mathrm{L}^{-1}$; 
$\left[\mathrm{k}_{\mathrm{H}_{2} \mathrm{O}_{2}}\right]$ is the reaction rate constant of $\mathrm{H}_{2} \mathrm{O}_{2}$ degradation of $\mathrm{COD}_{\mathrm{Cr}}, \mathrm{L}(\mathrm{mol} \mathrm{s})^{-1}$; and [HO•] is the reaction rate constant of $\mathrm{HO} \bullet$ degradation of $\mathrm{COD}_{\mathrm{Cr}}, \mathrm{L}(\mathrm{mol} \mathrm{s})^{-1}$.

Preliminary experiments indicated that $\mathrm{H}_{2} \mathrm{O}_{2}$ alone elicits a negligible degradation effect on $\mathrm{COD}_{\mathrm{Cr}}$ in coalbed methane-produced water in backflow stage; therefore, Equation (10) can be simplified as follows:

$$
\frac{\mathrm{d}\left[\mathrm{COD}_{\mathrm{Cr}}\right]}{\mathrm{dt}}=\mathrm{k}_{\mathrm{OH}} \cdot\left[\mathrm{COD}_{\mathrm{Cr}}\right]
$$

If $\mathrm{k}_{\mathrm{HO}}[\mathrm{HO} \bullet]$ is considered as $k$, then $k$ is the apparent reaction rate constant of a heterogeneous Fenton reaction that degrades $\mathrm{COD}_{\mathrm{Cr}}$.

By integrating Equation (11),

$$
\ln \frac{\left[\mathrm{COD}_{\mathrm{Cr}}\right]}{\left[\mathrm{COD}_{\mathrm{Cr}}\right]_{0}}=\mathrm{kt}
$$

Based on the apparent reaction kinetics, $\ln \left(\left[\mathrm{COD}_{\mathrm{Cr}}\right] /\left[\mathrm{COD}_{\mathrm{Cr}}\right]_{0}\right)$ was plotted against $t$, followed by linear fitting. Thus, the apparent reaction rate equation of the heterogeneous Fenton reaction of $\mathrm{COD}_{\mathrm{Cr}}$ degradation was obtained.

In our earlier experiment, $\mathrm{COD}_{\mathrm{Cr}}$ degradation completely occurred in $75 \mathrm{~min}$ in coalbed methane-produced water via heterogeneous Fenton reaction. Thus, for the following discussion of kinetics, the data from the reaction at $75 \mathrm{~min}$ were used.

\subsection{Degradation Kinetics of CODCr in Coalbed Methane-Produced Water with Different Initial pH Values}

In this section, we discuss the influence of initial $\mathrm{pH}$ values on the degradation kinetics of $\mathrm{COD}_{\mathrm{Cr}}$ via heterogeneous Fenton reaction. The experimental conditions were as follows: $25^{\circ} \mathrm{C}$, $\mathrm{H}_{2} \mathrm{O}_{2}$ concentration of $40 \mathrm{mmol} \mathrm{L}^{-1}$, catalyst concentration of $4 \mathrm{~g} \mathrm{~L}^{-1}$, initial $\mathrm{pH}$ of 2.5, 3.5, 5.1 (raw water), 6, and 7. The fitting results are shown in Figure 13 and Table 5.

Figure 13 and Table 5 show that $\mathrm{COD}_{\mathrm{Cr}}$ degradation in coalbed methane-produced water in the experimental range of initial $\mathrm{pH}$ (2.5 to 7) is in accordance with pseudo-first-order kinetics. The apparent reaction rate constants of $\mathrm{COD}_{\mathrm{Cr}}$ degradation are $-0.0133,-0.0172,-0.0113,-0.005$, and $-0.003 \mathrm{~min}^{-1}$ when initial $\mathrm{pH}$ values are $2.5,3.5,5.1,6$, and 7 , respectively.

The initial $\mathrm{pH}$ is necessary to stimulate Fenton reaction; an acidic condition is favorable for $\mathrm{HO} \bullet$ generation. As the initial $\mathrm{pH}$ decreases, the apparent reaction rate constant increases. When the $\mathrm{pH}$ is very low, active components may on the catalyst surface exist as ${\mathrm{M}-\mathrm{OH}_{2}}^{-}$( $\mathrm{M}$ is a metal ion), which adversely affects $\mathrm{HO} \bullet$ production [61]; therefore, the apparent reaction rate constant decreases. The reaction proceeds at the fastest speed when the initial $\mathrm{pH}$ is 3.5 , and the apparent reaction rate constant is $-0.0172 \mathrm{~min}^{-1}$.

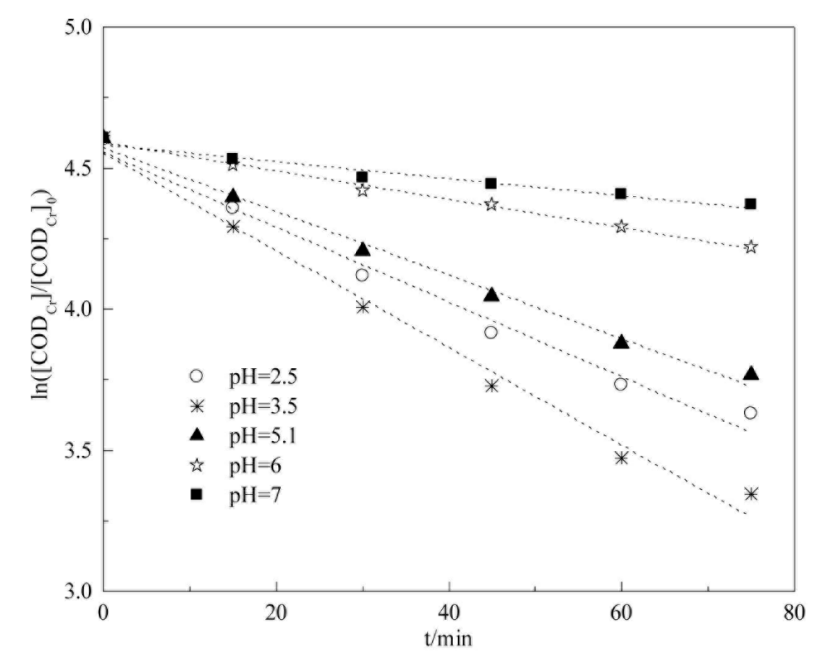

Figure 13. Effect of apparent rate constant on different initial $\mathrm{pH}$ values. 
Table 5. Apparent reaction rate constant of different initial $\mathrm{pH}$ values.

\begin{tabular}{cccc}
\hline Initial $\mathbf{p H}$ Values & Linear Fitting Equation & Apparent Reaction Rate Constant $\left(\mathbf{m i n}^{\mathbf{- 1}}\right)$ & $\mathbf{R}^{\mathbf{2}}$ \\
\hline 2.5 & $\mathrm{y}=-0.0133 \mathrm{x}+4.5562$ & -0.0133 & 0.9837 \\
3.5 & $\mathrm{y}=-0.0172 \mathrm{x}+4.5538$ & -0.0172 & 0.9873 \\
5.1 & $\mathrm{y}=-0.0113 \mathrm{x}+4.5728$ & -0.0113 & 0.9919 \\
6 & $\mathrm{y}=-0.005 \mathrm{x}+4.5909$ & -0.005 & 0.9927 \\
7 & $\mathrm{y}=-0.003 \mathrm{x}+4.5832$ & -0.003 & 0.9615 \\
\hline
\end{tabular}

5.2. Analysis of Degradation Kinetics of CODCr in Coalbed Methane-Produced Water with Different $\mathrm{H}_{2} \mathrm{O}_{2}$ Concentrations

We examine the influence of $\mathrm{H}_{2} \mathrm{O}_{2}$ concentration on $\mathrm{COD}_{\mathrm{Cr}}$ degradation kinetics via heterogeneous Fenton reaction in this section. The experimental conditions were as follows: $25^{\circ} \mathrm{C}$, initial pH of 5.1 (raw water), catalyst dosage of $4 \mathrm{~g} \mathrm{~L}^{-1}, \mathrm{H}_{2} \mathrm{O}_{2}$ concentrations of $10,20,30,40$, and $50 \mathrm{mmol} \mathrm{L}^{-1}$, respectively. The fitting results are shown in Figure 14 and Table 6.

Figure 14 and Table 6 show that $\mathrm{COD}_{\mathrm{Cr}}$ degradation in coalbed methane-produced water is in accordance with pseudo-first-order kinetics in the experimental range of $\mathrm{H}_{2} \mathrm{O}_{2}$ concentration $\left(10 \mathrm{mmol} \mathrm{L}^{-1}\right.$ to $\left.50 \mathrm{mmol} \mathrm{L}{ }^{-1}\right)$. The apparent reaction rate constants of $\mathrm{COD}_{\mathrm{Cr}}$ degradation are $-0.0034,-0.0041,-0.0076,-0.0111$, and $-0.0085 \mathrm{~min}^{-1}$ when $\mathrm{H}_{2} \mathrm{O}_{2}$ concentrations are $10,20,30$, 40 , and $50 \mathrm{mmol} \mathrm{L}^{-1}$, respectively. The $\mathrm{H}_{2} \mathrm{O}_{2}$ concentration is directly related to the $\mathrm{HO} \bullet$ yield. As the $\mathrm{H}_{2} \mathrm{O}_{2}$ concentration increases, the apparent reaction rate constant increases; however, $\mathrm{H}_{2} \mathrm{O}_{2}$ becomes a scavenging agent of $\mathrm{HO} \bullet$ when the $\mathrm{H}_{2} \mathrm{O}_{2}$ concentration is very high; therefore, the apparent reaction rate constant decreases. The reaction reaches the largest value when the $\mathrm{H}_{2} \mathrm{O}_{2}$ concentration is $40 \mathrm{mmol} \mathrm{L}^{-1}$, and the apparent reaction rate constant is $-0.0111 \mathrm{~min}^{-1}$.

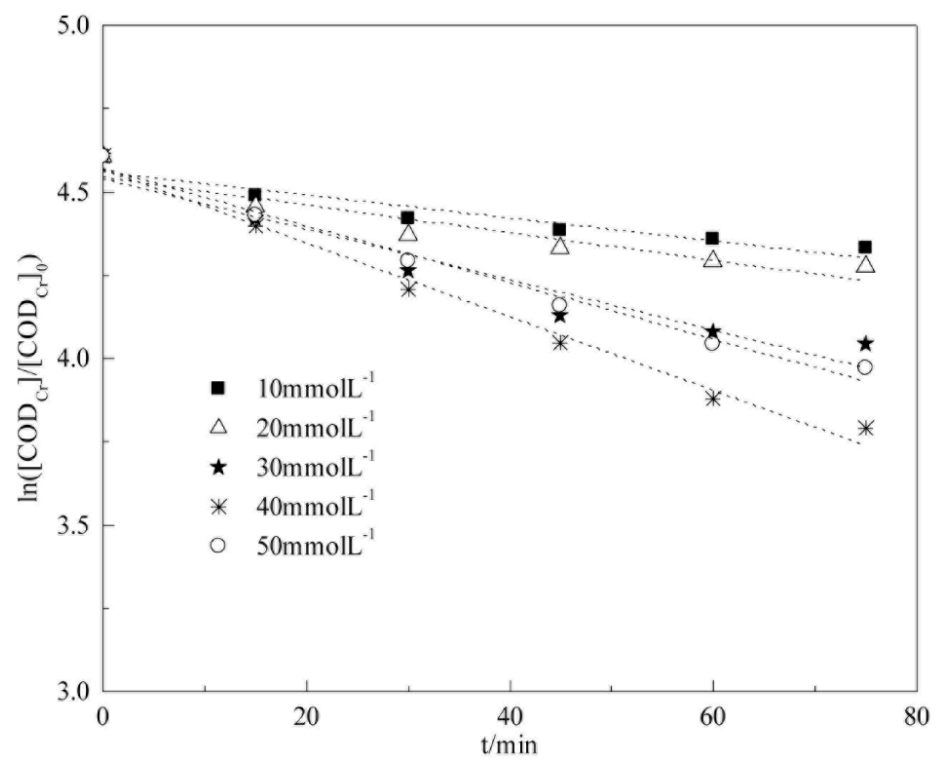

Figure 14. Effect of apparent rate constant on different $\mathrm{H}_{2} \mathrm{O}_{2}$ concentrations.

Table 6. Apparent reaction rate constant of different $\mathrm{H}_{2} \mathrm{O}_{2}$ concentrations.

\begin{tabular}{cccc}
\hline $\mathbf{H}_{\mathbf{2}} \mathbf{O}_{\mathbf{2}}$ Concentration & Linear Fitting Equation & Apparent Reaction Rate Constant $\left(\mathbf{m i n}^{\mathbf{- 1}}\right)$ & $\mathbf{R}^{\mathbf{2}}$ \\
\hline $10 \mathrm{mmol} \mathrm{L}^{-1}$ & $\mathrm{y}=-0.0034 \mathrm{x}+4.56$ & -0.0034 & 0.930 \\
$20 \mathrm{mmol} \mathrm{L}^{-1}$ & $\mathrm{y}=-0.0041 \mathrm{x}+4.54$ & -0.0041 & 0.935 \\
$30 \mathrm{mmol} \mathrm{L}^{-1}$ & $\mathrm{y}=-0.0076 \mathrm{x}+4.54$ & -0.0076 & 0.969 \\
$40 \mathrm{mmol} \mathrm{L}^{-1}$ & $\mathrm{y}=-0.0111 \mathrm{x}+4.57$ & -0.0111 & 0.988 \\
$50 \mathrm{mmol} \mathrm{L}^{-1}$ & $\mathrm{y}=-0.0085 \mathrm{x}+4.57$ & -0.0085 & 0.985 \\
\hline
\end{tabular}




\subsection{Analysis on Degradation Kinetics of $C O D_{C r}$ in Coalbed Methane-Produced Water with Different Catalyst Concentrations}

This section investigates the effect of catalyst concentration on $\mathrm{COD}_{\mathrm{Cr}}$ degradation kinetics via heterogeneous Fenton reaction. The experimental conditions were as follows: $25{ }^{\circ} \mathrm{C}, \mathrm{H}_{2} \mathrm{O}_{2}$ concentration of $40 \mathrm{mmol} \mathrm{L}^{-1}$, initial $\mathrm{pH}$ of 5.1 (raw water), catalyst concentrations of $0.5,1,2,4$, and $8 \mathrm{~g} \mathrm{~L}^{-1}$, respectively. The fitting results are shown in Figure 15 and Table 7.

Figure 15 and Table 7 show that $\mathrm{COD}_{\mathrm{Cr}}$ degradation in coalbed methane-produced water in the experimental catalyst dosage range $\left(0.5 \mathrm{~L}^{-1}\right.$ to $\left.8 \mathrm{~L}^{-1}\right)$ is in accordance with pseudo-first-order kinetics. The apparent reaction rate constants of $\mathrm{COD}_{\mathrm{Cr}}$ degradation are $-0.0036,-0.0048,-0.0063,-0.0111$, and $-0.0087 \mathrm{~min}^{-1}$ when catalyst concentrations are $0.5,1,2,4$, and $8 \mathrm{~g} \mathrm{~L}^{-1}$, respectively.

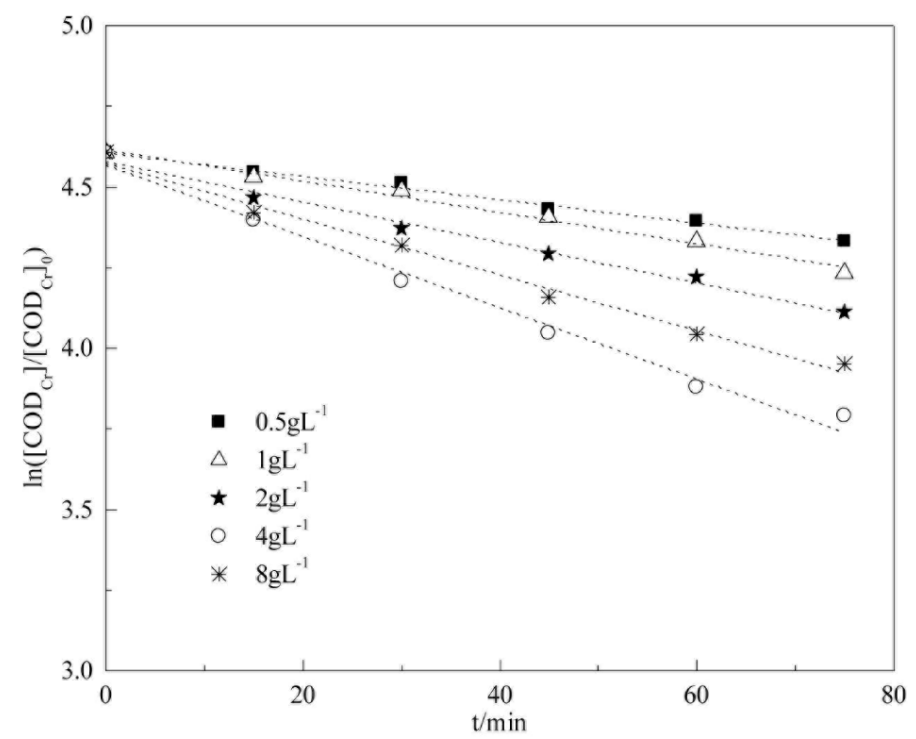

Figure 15. Effect of apparent rate constant on different catalyst concentrations.

Table 7. Apparent reaction rate constant of different catalyst concentrations.

\begin{tabular}{cccc}
\hline $\mathbf{H}_{\mathbf{2}} \mathbf{O}_{\mathbf{2}}$ Concentration & Linear Fitting Equation & Apparent Reaction Rate Constant $\left.\mathbf{m i n}^{-\mathbf{1}}\right)$ & $\mathbf{R}^{\mathbf{2}}$ \\
\hline $0.5 \mathrm{~g} \mathrm{~L}^{-1}$ & $\mathrm{y}=-0.0036 \mathrm{x}+4.60$ & -0.0036 & 0.992 \\
$1 \mathrm{~g} \mathrm{~L}^{-1}$ & $\mathrm{y}=-0.0048 \mathrm{x}+4.61$ & -0.0048 & 0.989 \\
$2 \mathrm{~g} \mathrm{~L}^{-1}$ & $\mathrm{y}=-0.0063 \mathrm{x}+4.58$ & -0.0063 & 0.988 \\
$4 \mathrm{~g} \mathrm{~L}^{-1}$ & $\mathrm{y}=-0.0111 \mathrm{x}+4.57$ & -0.0111 & 0.987 \\
$8 \mathrm{~g} \mathrm{~L}^{-1}$ & $\mathrm{y}=-0.0087 \mathrm{x}+4.57$ & -0.0087 & 0.990 \\
\hline
\end{tabular}

As the catalyst concentration increases, the apparent reaction rate constant increases. This increase occurs because more active sites become available for catalysis when high catalyst concentrations are present. However, the apparent reaction rate constant decreases when the catalyst concentration exceeds a specific limit because excess amounts of $\mathrm{HO} \bullet$ interact. The reaction speed reaches the largest value when the catalyst concentration is $4 \mathrm{~g} \mathrm{~L}^{-1}$, and the apparent reaction rate constant is $-0.0111 \mathrm{~min}^{-1}$.

\subsection{Heterogeneous/Homogeneous Catalysis Comparison Testing}

The results for heterogeneous/homogeneous catalysis comparison testing is shown in Figure 16. Both reactions are tested under the same reaction conditions, except for the type of the catalysts. It can be seen that homogeneous catalysis reaction resulted in a higher performance of in $C O D_{c r}$ degradation than that of heterogeneous catalysis. This could be attributed to the fact that, due to the pore and channel overlap in the heterogeneous catalyst of $\mathrm{Fe}-\gamma-\mathrm{Al}_{2} \mathrm{O}_{3}$, not all Fe species can be exposed to the solution during the reaction. While all $\mathrm{Fe}^{2+}$ can be involved to the reaction in the 
homogeneous catalysis. Similar results with a higher catalytic performance of homogeneous catalyst over a heterogeneous catalyst were reported previously [62]. Even though the homogenous catalyst shows excellent performance in purifying wastewater, the heterogeneous catalyst is more superior in the practical reactions. This is because the heterogeneous catalyst can be easily separated from the water by filtration or other techniques after the Fenton reaction, and does not leave any residues. However, the homogenous catalyst $\left(\mathrm{Fe}^{2+}\right)$ is harder to separate from the water after reaction, and forms secondary pollutants [26].

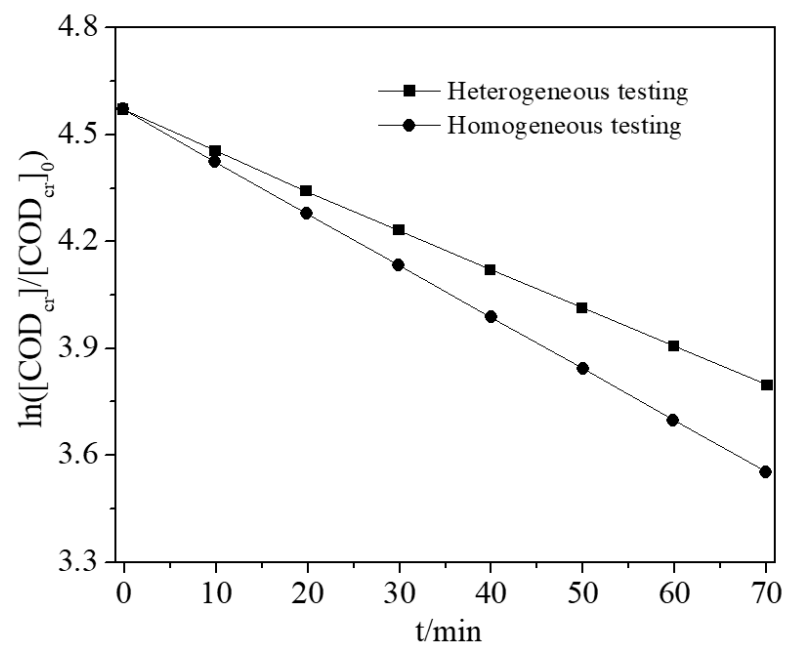

Figure 16. The results of heterogeneous/homogeneous catalysis comparison testing.

\section{Conclusions}

(1) In our study, we produced a new catalyst $\mathrm{Fe}-\mathrm{Co} / \gamma-\mathrm{Al}_{2} \mathrm{O}_{3}$ by a homogeneous precipitation method, and characterized it through SEM, EDS, XRD, XPS, FT-IR, BET, and XRF analysis. The result shows that synthetic $\mathrm{Fe} / \gamma-\mathrm{Al}_{2} \mathrm{O}_{3}, \mathrm{Fe}-\mathrm{Co} / \gamma-\mathrm{Al}_{2} \mathrm{O}_{3}$ catalysts has a large specific surface area and porous structure; in addition, active components exist in $\alpha-\mathrm{FeOOH}$ and $\mathrm{CoO}$ forms, which have good stability.

(2) The transition metal Co was added to a heterogeneous Fenton reaction, which greatly improved the catalytic activity of the carrier and degradation efficiency of the organics. In practical terms, compared with $\alpha-\mathrm{Fe} / \gamma-\mathrm{Al}_{2} \mathrm{O}_{3}$, the $\alpha-\mathrm{Fe}-\mathrm{Co} / \gamma-\mathrm{Al}_{2} \mathrm{O}_{3}$ catalyst elicits a greater catalytic effect because $\mathrm{Co}^{2+}$ can react with $\mathrm{H}_{2} \mathrm{O}_{2}$, thereby generating $\mathrm{HO} \bullet$. A redox reaction also occurs between $\mathrm{Co}^{2+}$ and $\mathrm{Fe}^{3+}$; this reaction facilitates electron transfer and accelerates conversion and cycle among metals with different valences. As a result, $\mathrm{HO} \bullet$ efficiency is improved.

(3) During the reuse of the Fe-Co $/ \gamma-\mathrm{Al}_{2} \mathrm{O}_{3}$ catalyst, a specific amount of active components are filtered. According to the experimental data, the amount of $\mathrm{Fe}+\mathrm{Co}$ lost through filtration is small, which can be ignored. The result shows that the produced $\mathrm{Fe}-\mathrm{Co} / \gamma-\mathrm{Al}_{2} \mathrm{O}_{3}$ catalyst in the experiment is stable and reusable.

(4) According to the experimental data and classical reaction kinetics theory, we established the overall reaction kinetics, which result in $\mathrm{COD}_{\mathrm{Cr}}$ degradation in coalbed methane-produced water during Fenton catalytic oxidation. Under different conditions, $\mathrm{COD}_{\mathrm{Cr}}$ degradation in coalbed methane-produced water meets the pseudo-first-order kinetics. The optimal conditions are that the initial $\mathrm{pH}$ is $3.5, \mathrm{H}_{2} \mathrm{O}_{2}$ concentration is $40 \mathrm{~mol} \mathrm{~L}^{-1}$, catalyst concentration is $4 \mathrm{~g} \mathrm{~L}^{-1}$, and apparent reaction rate constant is $-0.0172 \mathrm{~min}^{-1}$.

Author Contributions: Wei Gu conceived and designed the experiments; Meng Zhang performed the experiments; Wei $\mathrm{Gu}$ analyzed the data; Meng Zhang contributed reagents/materials/analysis tools. Meng Zhang and Wei Gu wrote the paper. 
Acknowledgments: Research reported in this paper was supported by the Open Projects of State Key Laboratory of Coal Resources and Safe Mining, CUMT (No. SKLCRSM13X08).

Conflicts of Interest: The authors declare no conflicts of interest.

\section{References}

1. Coalbed gas systems, resources, and production and a review of contrasting cases from the San Juan and powder river basins. AAPG Bull. 2002, 86, 1853-1890.

2. Flores, R.M.; Rice, C.A.; Stricker, G.D.; Warden, A.; Ellis, M.S. Methanogenic pathways of coal-bed gas in the powder river basin, United States: The geologic factor. Int. J. Coal Geol. 2008, 76, 52-75. [CrossRef]

3. Jha, R.; Dulikravich, G.S.; Chakraborti, N.; Fan, M.; Schwartz, J.; Koch, C.C.; Colaco, M.J.; Poloni, C.; Egorov, I.N. Algorithms for design optimization of chemistry of hard magnetic alloys using experimental data. J. Alloys Compd. 2016, 682, 454-467. [CrossRef]

4. Wang, X.; Xinxin Zhao, C.; Xu, G.; Chen, Z.-K.; Zhu, F. Degradation mechanisms in organic solar cells: Localized moisture encroachment and cathode reaction. Sol. Energy Mater. Sol. Cells 2012, 104, 1-6. [CrossRef]

5. Yan, H.; Zhao, C.; Wang, K.; Deng, L.; Ma, M.; Xu, G. Negative dielectric constant manifested by static electricity. Appl. Phys. Lett. 2013, 102, 062904. [CrossRef]

6. Zhao, C.X.; Xiao, S.; Xu, G. Density of organic thin films in organic photovoltaics. J. Appl. Phys. 2015, 118, 044510. [CrossRef]

7. Fan, M.; Liu, Y.; Jha, R.; Dulikravich, G.S.; Schwartz, J.; Koch, C.C. On the evolution of Cu-Ni-rich bridges of Alnico alloys with tempering. J. Magn. Magn. Mater. 2016, 420, 296-302. [CrossRef]

8. Wang, R.; Yang, C.; Fan, M.; Wu, M.; Wang, C.; Yu, X.; Zhu, J.; Zhang, J.; Li, G.; Huang, Q.; et al. Phase relationship of the $\mathrm{TbO}_{1.81}-\mathrm{Mn}_{3} \mathrm{O}_{4}-\mathrm{Fe}_{2} \mathrm{O}_{3}$ system synthesized at $1200^{\circ} \mathrm{C}$. J. Alloys Compd. 2013, 554, $385-394$. [CrossRef]

9. Zaddach, A.J.; Niu, C.; Oni, A.A.; Fan, M.; LeBeau, J.M.; Irving, D.L.; Koch, C.C. Structure and magnetic properties of a multi-principal element $\mathrm{Ni}-\mathrm{Fe}-\mathrm{Cr}-\mathrm{Co}-\mathrm{Zn}-\mathrm{Mn}$ alloy. Intermetallics 2016, 68, 107-112. [CrossRef]

10. Zhang, G.; Fan, M. Synthesis and magnetic properties of double b mixed perovskite series $\mathrm{La}_{0.75} \mathrm{~K}_{0.25} \mathrm{Mn}_{1}-\mathrm{xFe}_{\mathrm{x}} \mathrm{O}_{3}$. Chem. Lett. 2011, 40, 244-245. [CrossRef]

11. McMillen, S.J.; Smart, R.; Bernier, R.; Hoffmann, R.E. Biotreating e\&p wastes: Lessons learned from 1992-2003. In SPE International Conference on Health, Safety, and Environment in Oil and Gas Exploration and Production; Society of Petroleum Engineers: Calgary, AB, Canada, 2004.

12. Bansal, K.M.; Sugiarto, S. Exploration and production operations-Waste management a comparative overview: US and indonesia cases. In SPE Asia Pacific Oil and Gas Conference and Exhibition; Society of Petroleum Engineers: Jakarta, Indonesia, 1999.

13. Fan, M.; Liu, Y.; Jha, R.; Dulikravich, G.S.; Schwartz, J.; Koch, C.C. On the formation and evolution of $\mathrm{Cu}-\mathrm{Ni}$-rich bridges of alnico alloys with thermomagnetic treatment. IEEE Trans. Magn. 2016, 52, 1-10. [CrossRef]

14. Jha, R.; Dulikravich, G.S.; Colaço, M.J.; Fan, M.; Schwartz, J.; Koch, C.C. Magnetic alloys design using multi-objective optimization. In Properties and Characterization of Modern Materials; Öchsner, A., Altenbach, H., Eds.; Springer: Singapore, 2017; pp. 261-284.

15. Fan, M.; Li, G.-B.; Wang, D.-W.; Jin, T.-N.; Liao, F.-H.; Lin, J.-H. Synthesis, structure and characterization of $\mathrm{Pb}_{1-\mathrm{x}} \mathrm{Tb}_{\mathrm{x}} \mathrm{Ti}_{1-\mathrm{x}} \mathrm{Mn}_{\mathrm{x}} \mathrm{O}_{3}(0 \leq \mathrm{x} \leq 0.10)$ solid solutions. Acta Physico-Chimica Sinica 2011, 27, 990-994.

16. Zhao, C.X.; Wang, X.; Zeng, W.; Chen, Z.K.; Ong, B.S.; Wang, K.; Deng, L.; Xu, G. Organic photovoltaic power conversion efficiency improved by AC electric field alignment during fabrication. Appl. Phys. Lett. 2011, 99, 053305. [CrossRef]

17. Chen, J.; Zhao, C.X.; Zhi, M.M.; Wang, K.; Deng, L.; Xu, G. Alkaline direct oxidation glucose fuel cell system using silver/nickel foams as electrodes. Electrochim. Acta 2012, 66, 133-138. [CrossRef]

18. Deng, L.L.; Zhao, C.X.; Ma, Y.; Chen, S.S.; Xu, G. Low cost acetone sensors with selectivity over water vapor based on screen printed $\mathrm{TiO}_{2}$ nanoparticles. Anal. Methods 2013, 5, 3709-3713. [CrossRef]

19. Zhao, C.X.; Mao, A.Y.; Xu, G. Junction capacitance and donor-acceptor interface of organic photovoltaics. Appl. Phys. Lett. 2014, 105, 063302. [CrossRef] 
20. Floyd, R.A.; Lewis, C.A. Hydroxyl free radical formation from hydrogen peroxide by ferrous iron-nucleotide complexes. Biochemistry 1983, 22, 2645-2649. [CrossRef] [PubMed]

21. Lloyd, R.V.; Hanna, P.M.; Mason, R.P. The origin of the hydroxyl radical oxygen in the fenton reaction. Free Radic. Biol. Med. 1997, 22, 885-888. [CrossRef]

22. Lakey, P.S.J.; Berkemeier, T.; Tong, H.; Arangio, A.M.; Lucas, K.; Pöschl, U.; Shiraiwa, M. Chemical exposure-response relationship between air pollutants and reactive oxygen species in the human respiratory tract. Sci. Rep. UK 2016, 6, 32916. [CrossRef] [PubMed]

23. Ma, J.; Ma, W.; Song, W.; Chen, C.; Tang, Y.; Zhao, J.; Huang, Y.; Xu, Y.; Zang, L. Fenton degradation of organic pollutants in the presence of low-molecular-weight organic acids: Cooperative effect of quinone and visible light. Environ. Sci. Technol. 2006, 40, 618-624. [CrossRef] [PubMed]

24. Carra, I.; Ortega-Gómez, E.; Santos-Juanes, L.; Casas López, J.L.; Sánchez Pérez, J.A. Cost analysis of different hydrogen peroxide supply strategies in the solar photo-fenton process. Chem. Eng. J. 2013, 224, 75-81. [CrossRef]

25. Bandala, E.R.; Velasco, Y.; Torres, L.G. Decontamination of soil washing wastewater using solar driven advanced oxidation processes. J. Hazard. Mater. 2008, 160, 402-407. [CrossRef] [PubMed]

26. Lewinsky, A.A. Hazardous Materials and Wastewater: Treatment, Removal and Analysis; Nova Science Publishers: Hauppauge, NY, USA, 2007.

27. Enami, S.; Sakamoto, Y.; Colussi, A.J. Fenton chemistry at aqueous interfaces. Proc. Natl. Acad. Sci. USA 2014, 111, 623-628. [CrossRef] [PubMed]

28. Bautista, P.; Mohedano, A.F.; Menéndez, N.; Casas, J.A.; Rodriguez, J.J. Catalytic wet peroxide oxidation of cosmetic wastewaters with fe-bearing catalysts. Catal. Today 2010, 151, 148-152. [CrossRef]

29. Cheng, X.; Wiggins, J.S. Continuous reactor preparation of thermoplastic modified epoxy-amine prepolymers. Polym. Int. 2014, 63, 1777-1784. [CrossRef]

30. Cheng, X.; Wu, Q.; Morgan, S.E.; Wiggins, J.S. Morphologies and mechanical properties of polyethersulfone modified epoxy blends through multifunctional epoxy composition. J. Appl. Polym. Sci. 2017, 134. [CrossRef]

31. Liu, X.; Bhatia Surita, R. Laponite ${ }^{\circledR}$ and Laponite ${ }^{\circledR}-\mathrm{PEO}$ hydrogels with enhanced elasticity in phosphate-buffered saline. Polym. Adv. Technol. 2015, 26, 874-879. [CrossRef]

32. Liu, X.; Liu, W.; Carr, A.J.; Santiago Vazquez, D.; Nykypanchuk, D.; Majewski, P.W.; Routh, A.F.; Bhatia, S.R. Stratification during evaporative assembly of multicomponent nanoparticle films. J. Colloid Interface Sci. 2018, 515, 70-77. [CrossRef] [PubMed]

33. Oku, M.; Hirokawa, K. X-ray photoelectron spectroscopy of $\mathrm{Co}_{3} \mathrm{O}_{4}, \mathrm{Fe}_{3} \mathrm{O}_{4}, \mathrm{Mn}_{3} \mathrm{O}_{4}$, and related compounds. J. Electron Spectrosc. Relat. Phenomena 1976, 8, 475-481. [CrossRef]

34. Deng, L.; Wang, K.; Zhao, C.X.; Yan, H.; Britten, J.F.; Xu, G. Phase and texture of solution-processed copper phthalocyanine thin films investigated by two-dimensional grazing incidence $X$-ray diffraction. Crystals 2011, 1, 112-119. [CrossRef]

35. Wang, K.K.; Yan, H.; Zhao, C.X.; Xu, G.; Qi, Y.; Wu, Y.; Hu, N.-X. Direct method of tracing the wetting states on nanocomposite surfaces. Langmuir 2010, 26, 7686-7689. [CrossRef] [PubMed]

36. Iacomi, F.; Calin, G.; Scarlat, C.; Irimia, M.; Doroftei, C.; Dobromir, M.; Rusu, G.G.; Iftimie, N.; Sandu, A.V. Functional properties of nickel cobalt oxide thin films. Thin Solid Films 2011, 520, 651-655. [CrossRef]

37. Schanke, D.; Hilmen, A.M.; Bergene, E.; Kinnari, K.; Rytter, E.; Ådnanes, E.; Holmen, A. Study of the deactivation mechanism of $\mathrm{Al}_{2} \mathrm{O}_{3}$-supported cobalt fischer-tropsch catalysts. Catal. Lett. 1995, 34, $269-284$. [CrossRef]

38. Ma, Y.; Zhao, C.X.; Deng, L.L.; Yan, H.; Chen, S.S.; Xu, G. Transition of pore-size dependence of ion diffusivity in dye-sensitized solar cells. Electrochim. Acta 2013, 102, 127-132. [CrossRef]

39. Zhao, C.X.; Deng, L.L.; Ma, M.Y.; Kish, J.R.; Xu, G. Multiple-interface tracking of degradation process in organic photovoltaics. AIP Adv. 2013, 3, 102121. [CrossRef]

40. Cui, X.; Zhu, G.; Pan, Y.; Shao, Q.; Zhao, C.; Dong, M.; Zhang, Y.; Guo, Z. Polydimethylsiloxane-titania nanocomposite coating: Fabrication and corrosion resistance. Polymer 2018, 138, 203-210. [CrossRef]

41. Daud, N.K.; Hameed, B.H. Decolorization of acid red 1 by fenton-like process using rice husk ash-based catalyst. J. Hazard. Mater. 2010, 176, 938-944. [CrossRef] [PubMed]

42. Zhang, Q.; Jiang, W.-F.; Wang, H.-L.; Chen, M.-D. Oxidative degradation of dinitro butyl phenol (dnbp) utilizing hydrogen peroxide and solar light over a $\mathrm{Al}_{2} \mathrm{O}_{3}$-supported $\mathrm{Fe}$ (III)-5-sulfosalicylic acid (ssal) catalyst. J. Hazard. Mater. 2010, 176, 1058-1064. [CrossRef] [PubMed] 
43. Zhao, J.; Ge, S.; Liu, L.; Shao, Q.; Mai, X.; Zhao, C.X.; Hao, L.; Wu, T.; Yu, Z.; Guo, Z. Microwave solvothermal fabrication of zirconia hollow microspheres with different morphologies using pollen templates and their dye adsorption removal. Ind. Eng. Chem. Res. 2018, 57, 231-241. [CrossRef]

44. Chen, S.S.; Zhao, C.X.; Mao, A.Y.; Li, R.W.; Xu, G. Non-zero output from a symmetrical organic photovoltaic device. Synth. Met. 2014, 197, 75-79. [CrossRef]

45. Parida, K.M.; Pradhan, A.C. Fe/meso- $\mathrm{Al}_{2} \mathrm{O}_{3}$ : An efficient photo-fenton catalyst for the adsorptive degradation of phenol. Ind. Eng. Chem. Res. 2010, 49, 8310-8318. [CrossRef]

46. Šarić, A.; Musić, S.; Nomura, K.; Popović, S. Microstructural properties of Fe-oxide powders obtained by precipitation from $\mathrm{FeCl}_{3}$ solutions. Mater. Sci. Eng. B 1998, 56, 43-52. [CrossRef]

47. Schwertmann, U.; Cornell, R.M. The iron oxides. In Iron Oxides in the Laboratory; Wiley-VCH Verlag GmbH: Weinheim, Germany, 2007; pp. 5-18.

48. Sing, K.S.W.; Everett, D.H.; Haul, R.A.W.; Moscou, L.; Pierotti, R.A.; Rouquérol, J.; Siemieniewska, T. Reporting physisorption data for gas/solid systems with special reference to the determination of surface area and porosity. Pure Appl. Chem. 1985, 57, 603-619. [CrossRef]

49. Strlič, M.; Kolar, J.; Šelih, V.; Kocar, D.; Pihlar, B. A Comparative Study of Several Transition Metals in Fenton-Like Reaction Systems at Circum-Neutral pH. Acta Chimica Slovenica 2003, 50, 619-632.

50. Costa, R.C.C.; Lelis, M.d.F.F.; Oliveira, L.C.A.; Fabris, J.D.; Ardisson, J.D.; Rios, R.R.V.A.; Silva, C.N.; Lago, R.M. Remarkable effect of $\mathrm{Co}$ and $\mathrm{Mn}$ on the activity of $\mathrm{Fe}_{3}-\mathrm{xM}_{\mathrm{x}} \mathrm{O}_{4}$ promoted oxidation of organic contaminants in aqueous medium with $\mathrm{H}_{2} \mathrm{O}_{2}$. Catal. Commun. 2003, 4, 525-529. [CrossRef]

51. Magalhães, F.; Pereira, M.C.; Botrel, S.E.C.; Fabris, J.D.; Macedo, W.A.; Mendonça, R.; Lago, R.M.; Oliveira, L.C.A. Cr-containing magnetites $\mathrm{Fe}_{3}-\mathrm{xCr}_{\mathrm{x}} \mathrm{O}_{4}$ : The role of $\mathrm{Cr}^{3+}$ and $\mathrm{Fe}^{2+}$ on the stability and reactivity towards $\mathrm{H}_{2} \mathrm{O}_{2}$ reactions. Appl. Catal. A Gen. 2007, 332, 115-123. [CrossRef]

52. Arnold, S.M.; Hickey, W.J.; Harris, R.F. Degradation of atrazine by fenton's reagent: Condition optimization and product quantification. Environ. Sci. Technol. 1995, 29, 2083-2089. [CrossRef] [PubMed]

53. Harber, F.; Weiss, J. The catalytic decomposition of hydrogen peroxide by iron salts. Proc. R. Soc. Lond. Ser. A Math. Phys. Sci. 1934, 147, 332-351. [CrossRef]

54. Gonzalez-Olmos, R.; Martin, M.J.; Georgi, A.; Kopinke, F.-D.; Oller, I.; Malato, S. Fe-zeolites as heterogeneous catalysts in solar fenton-like reactions at neutral ph. Appl. Catal. B Environ. 2012, 125, 51-58. [CrossRef]

55. Huang, R.; Fang, Z.; Yan, X.; Cheng, W. Heterogeneous sono-fenton catalytic degradation of bisphenol a by $\mathrm{Fe}_{3} \mathrm{O}_{4}$ magnetic nanoparticles under neutral condition. Chem. Eng. J. 2012, 197, 242-249. [CrossRef]

56. He, J.; Ma, W.; He, J.; Zhao, J.; Yu, J.C. Photooxidation of Azo dye in aqueous dispersions of $\mathrm{H}_{2} \mathrm{O}_{2} / \alpha$-feooh. Appl. Catal. B Environ. 2002, 39, 211-220. [CrossRef]

57. Yaping, Z.; Jiangyong, H. Photo-fenton degradation of $17 \beta$-estradiol in presence of $\alpha$-feoohr and $\mathrm{H}_{2} \mathrm{O}_{2}$. Appl. Catal. B Environ. 2008, 78, 250-258. [CrossRef]

58. Fernandez, J.; Bandara, J.; Lopez, A.; Buffat, P.; Kiwi, J. Photoassisted fenton degradation of nonbiodegradable Azo dye (orange II) in fe-free solutions mediated by cation transfer membranes. Langmuir 1999, 15, 185-192. [CrossRef]

59. Ramirez, J.H.; Maldonado-Hódar, F.J.; Pérez-Cadenas, A.F.; Moreno-Castilla, C.; Costa, C.A.; Madeira, L.M. Azo-dye orange II degradation by heterogeneous Fenton-like reaction using carbon-Fe catalysts. Appl. Catal. B Environ. 2007, 75, 312-323. [CrossRef]

60. Andreozzi, R.; Caprio, V.; Marotta, R. Oxidation of 3,4-dihydroxybenzoic acid by means of hydrogen peroxide in aqueous goethite slurry. Water Res. 2002, 36, 2761-2768. [CrossRef]

61. Andreozzi, R.; Caprio, V.; Marotta, R. Iron(III) (hydr)oxide-mediated photooxidation of 2-aminophenol in aqueous solution: A kinetic study. Water Res. 2003, 37, 3682-3688. [CrossRef]

62. Xavier, S.; Gandhimathi, R.; Nidheesh, P.V.; Ramesh, S.T. Comparison of homogeneous and heterogeneous fenton processes for the removal of reactive dye magenta $\mathrm{mb}$ from aqueous solution. Desalin. Water Treat. 2015, 53, 109-118. [CrossRef]

(C) 2018 by the authors. Licensee MDPI, Basel, Switzerland. This article is an open access article distributed under the terms and conditions of the Creative Commons Attribution (CC BY) license (http:/ / creativecommons.org/licenses/by/4.0/). 